\title{
ANÁLISE COMPARATIVA DA EMBRIOGÊNESE SOMÁTICA EM Citrus sinensis, var. Valência, e Citrus limonia, var. Limão Cravo
}

JOANNE NEVES MORAES

\begin{abstract}
Dissertação apresentada à Escola Superior de Agricultura "Luiz de Queiroz", Universidade de São Paulo, para obtenção do título de Mestre em Ciências, Área de concentração: Fisiologia e Bioquímica de Plantas.
\end{abstract}

Pir a cic a b a

Estado de São Paulo - Brasil

Agosto - 2003 


\title{
ANÁLISE COMPARATIVA DA EMBRIOGÊNESE SOMÁTICA EM Citrus sinensis, var. Valência, e Citrus limonia, var. Limão Cravo
}

\author{
Joanne Neves Moraes
}

Engenheira Agrônoma

Orientadora: Prof $^{\mathrm{a}}$. Dr ${ }^{\mathrm{a}}$. ADRIANA PINHEIRO MARTINELLI RODRIGUEZ

Dissertação apresentada à Escola Superior de Agricultura "Luiz de Queiroz", Universidade de São Paulo, para obtenção do título de Mestre em Ciências, Área de concentração: Fisiologia e Bioquímica de Plantas.

\author{
Piracicaba \\ Estado de São Paulo - Brasil \\ Agosto - 2003
}




\section{Dados Internacionais de Catalogacão na Publicação (CIP) DIVISÃO DE BIBLIOTECA E DOCUMENTAÇÃO - ESALQ/USP}

Moraes, Joanne Neves

Análise comparativa da embriogênese somática em Citrus sinensis, var. Valência, e Citrus limonia, var. Limão Cravo / Joanne Neves Moraes. - Piracicaba, 2003.

$77 \mathrm{p}$.

Dissertação (mestrado) - - Escola Superior de Agricultura Luiz de Queiroz, 2003.

Bibliogratia.

1. Embriogênese somática 2. Expressão gênica 3. Laranja 4. Limão 5. Marcador molecular I. Titulo

CDD 634.31

"Permitida a cópia total ou parcial deste documento, desde que citada a fonte - $\mathrm{O}$ autor" 


\section{DEDICO}

Aos meus amados pais, João e Ana

Aos meus irmãos Junior, Jamile e Jonathan

Aos meus avós, Valdomiro (in memorian) e Maninha

Pelo AMOR que nos une, e por sempre apoiarem os meus sonhos.

OFEREÇO

Ao Rodrigo por todo apoio, incentivo e principalmente pelo amor.

"A falsa ciência gera ateus; a verdadeira ciência leva o homem a se curvar diante da divindade". (Voltaire) 


\section{AGRADECIMENTOS}

A Deus, o Grande Arquiteto do Universo, pela minha existência.

Aos meus pais pelo constante incentivo e apoio na formação moral e intelectual dos seus filhos.

À Escola Superior de Agricultura "Luiz de Queiroz" (ESALQ/USP), especialmente ao Departamento de Ciências Biológicas, pela oportunidade de realização do curso de Mestrado.

Ao Centro de Energia Nuclear na Agricultura (CENA/USP) pela possibilidade de utilização das instalações e desenvolvimento deste trabalho de pesquisa.

À CAPES pela bolsa de estudos concedida durante dois meses. A FAPESP, pela concessão de bolsa de estudos e apoio financeiro fornecido ao projeto de pesquisa.

À Prof ${ }^{\mathrm{a}}$. Dr ${ }^{\mathrm{a}}$. Adriana Pinheiro Martinelli Rodriguez, pela confiança, orientação, apoio, incentivo e amizade.

Ao Dr. Marcelo C. Dornelas, pela colaboração no desenvolvimento das análises de expressão gênica.

Aos professores e colegas do Curso de Pós-Graduação em Fisiologia e Bioquímica de Plantas, que formal ou informalmente contribuíram em minha formação.

Aos funcionários do Departamento de Ciências Biológicas da ESALQ/USP, em especial à secretária Solizete e aos funcionários do CENA/USP, em especial à Suzi pelo apoio e atenção dispensados. 
À bibliotecária Silvia Zinsly pelo auxílio da correção das referências bibliográficas.

À colega Sandra C. C. Arruda e em especial ao Márcio L. Tomaz pela colaboração na execução de algumas etapas do trabalho. Obrigadooo!!!

Ao João Geraldo, do Laboratório de Instrumentação e Informática (CENA/USP), pela colaboração e pelos serviços de computação gráfica.

Aos amigos do Laboratório de Biotecnologia Vegetal (CENA/USP): Fernanda, Raquel, Cantídio, Herika, Gustavo, Fernando, Girlene, Nailton, Graça, Carol, Lílian, Mayra, Raphaele, Bonassa, Regina, Alessandra e Mônica (Lab. Histopatologia Vegetal) pelo apoio e amizade durante o desenvolvimento deste trabalho. Valeu pessoal!!

À Escola de Agronomia da UFBA pela formação moral e científica e, em especial aos professores Weliton, Clóvis, Ana Cristina Loyola, e Joelito pela amizade, constante incentivo e apoio.

Ao Dr. Jorge L. Loyola Dantas, Dr. Antônio da Silva Souza e todos do Laboratório de Biotecnologia Vegetal da EMBRAPA/CNPMF, pela orientação, amizade e por serem grandes incentivadores do meu Mestrado.

Ao Grupo de estudos do CEMAL e COEM pelos grandes ensinamentos e amizade.

À colega Silvana pelo apoio nos primeiros meses em Piracicaba e ao amigo Pedro Louça e família pela disposição, amizade e grande apoio, inclusive financeiro, no período sem bolsa.

À amiga de sempre, Tânia pela amizade constante e apoio mesmo à distância em todos os momentos.

À amiga Janaynna pelo companheirismo, amizade, alegrias e angústias compartilhadas dentro e fora de casa.

Aos amigos de hoje e sempre: Liliane (Lilix), Adriana (Dri), Daniela (Arara), Marisa, Lea, Flávio, Maria Graziela (Zizi), Paulo Celso e Alice pela amizade, apoio, alegrias partilhadas e carinho. Obrigada!!!!! 
À minha família, em especial aos meus irmãos pelo amor e amizade que nos une, e ao meu tio Toninho e família pelo apoio e carinho.

Ao Rodrigo pelo amor, carinho, apoio em todos momentos e grande estímulo à realização deste trabalho.

A todos aqueles que contribuíram de alguma forma para a realização deste trabalho, meus sinceros e carinhosos agradecimentos. 


\section{SUMÁRIO}

Página

RESUMO

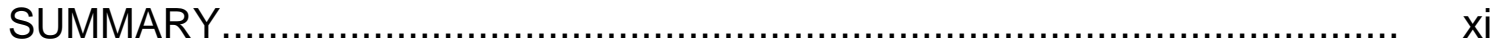

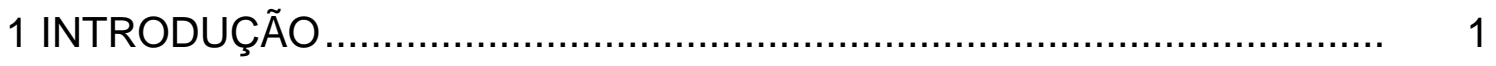

2 REVISÃO DE LITERATURA............................................................... 4

2.1 Embriogênese Somática em Citros.................................................... 6

2.2 Expressão Gênica e Embriogênese ............................................... 10

3 ANÁLISE COMPARATIVA DA EMBRIOGÊNESE SOMÁTICA DE Citrus sinensis E Citrus limonia ................................................................. 16

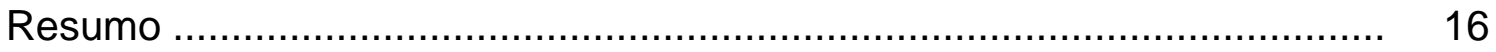

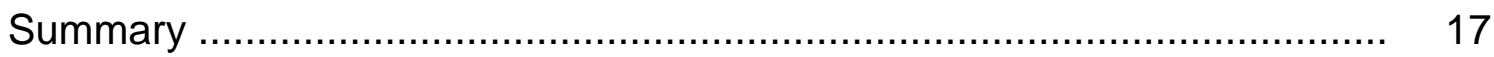

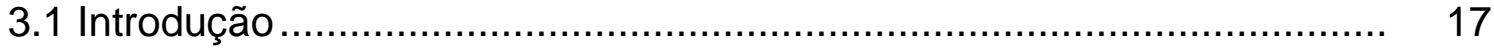

3.2 Material e Métodos …............................................................. 19

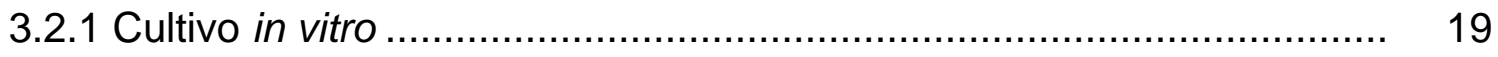

3.2.2 Análises Anatômicas e Histoquímicas ........................................... 19

3.2.3 Análise da Expressão Gênica ................................................... 20

3.2.3.1 Extração de Plasmídeos por Lise Alcalina ..................................... 20

3.2.3.2 Linearização dos Plasmídeos ................................................... 21

3.2.3.3 Marcação da Sonda Antisense ............................................... 22

3.2.3.4 Hibridização "in situ" .............................................................. 22

3.2.3.4.1 Preparo de Cortes histológicos .............................................. 22

3.3 Resultados e Discussão ......................................................... 24

3.3.1 Análises Anatômicas e Histoquímicas ............................................ 24 
3.3.2 Expressão do Gene SERK1 ................................................. 40

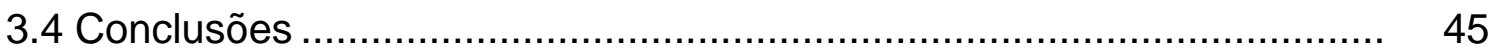

4 INFLUÊNCIA DO ESTRESSE E SEPARAÇÃO DE AGRUPAMENTOS CELULARES NA OBTENÇÃO DE EMBRIÕES SOMÁTICOS A PARTIR DE CULTURA DE CALOS EM CITRUS sinensis L. OSBECK ....................... 46

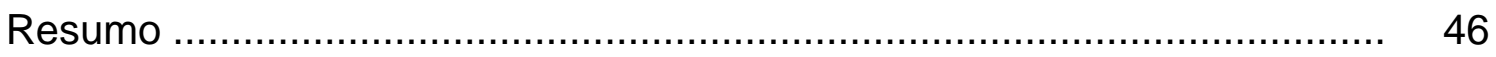

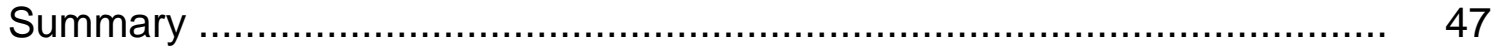

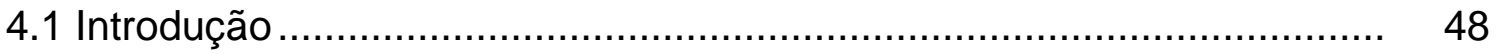

4.2 Material e Métodos ............................................................ 50

4.2.1 Cultivo In Vitro ................................................................. 50

4.2.2 Obtenção de Embriogênese Somática ……................................... 50

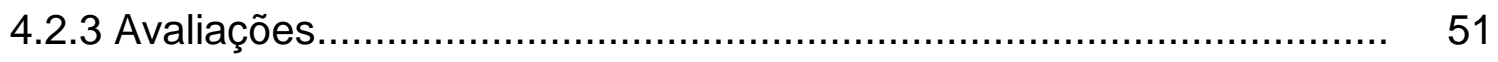

4.2.4 Análises Anatômicas e Histoquímicas ............................................. 53

4.3 Resultados e Discussão ................................................................. 54

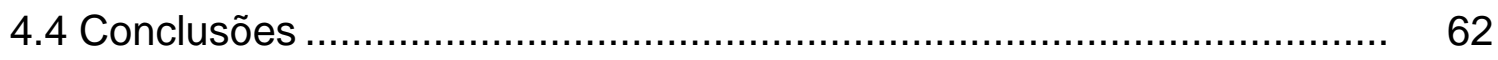

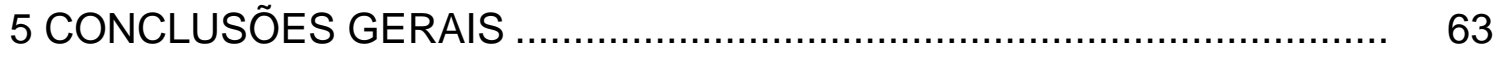

REFERÊNCIAS BIBLIOGRÁFICAS.................................................. 64 


\section{ANÁLISE COMPARATIVA DA EMBRIOGÊNESE SOMÁTICA EM Citrus sinensis, var. Valência, e Citrus limonia, var. Limão Cravo}

Autora: JOANNE NEVES MORAES

Orientadora: Prof ${ }^{\mathrm{a}}$. $\mathrm{Dr}^{\mathrm{a}}$. ADRIANA PINHEIRO MARTINELLI RODRIGUEZ

\section{RESUMO}

A embriogênese somática é uma técnica alternativa com potencial aplicação na propagação clonal de plantas, além de ser uma excelente ferramenta para estudos básicos e análise dos eventos moleculares e bioquímicos que ocorrem durante a embriogênese vegetal. Contudo, apesar de várias pesquisas relativas a embriogênese somática, a falta de conhecimento sobre os fatores que controlam o fenômeno, comprova que existem ainda muitos pontos a serem entendidos sobre o processo. Deste modo, o presente estudo foi concebido com o intuito de estudar a embriogênese somática de duas espécies de citros, as quais apresentam diferentes graus de eficiência na produção de embriões somáticos. Inicialmente, buscou-se avaliar comparativamente o processo de embriogênese somática de duas espécies de citros, observando-se as diferenças estruturais através de análises histológicas e histoquímicas, e as diferenças na expressão do gene AtSERK1 nos calos, através de hibridização in situ. Para instalação dos experimentos, foram utilizados calos provenientes de nucelos de duas espécies, Citrus sinensis L. Osbeck, variedade Valência, e Citrus limonia Osbeck, variedade limão 'Cravo'. Amostras de calos em meio de multiplicação, em meio de obtenção de 
embriões, e embriões somáticos nas diferentes fases de desenvolvimento foram coletados para observações anatômicas e histoquímicas através de microscopia óptica e realização de estudo da expressão gênica através de hibridização in situ. Com relação à morfologia, os principais resultados obtidos demonstraram que existem diferenças anatômicas e histoquímicas entre calos de limão 'Cravo' e 'Valência'. Em relação à expressão gênica, os resultados evidenciaram a expressão do gene AtSERK1 em calos das duas espécies de citros, tanto em meio de multiplicação, com sacarose, como em meio de indução, com maltose, indicando que o potencial embriogênico já está instalado no calo em meio de multiplicação. Pode-se concluir também que este gene é conservado entre Arabidopsis e Citrus. Desenvolveram-se, também, experimentos para estudar os efeitos de alguns tratamentos (frio, dessecação, agrupamentos celulares) na otimização da indução e sincronização da embriogênese somática de $C$. sinensis, var. Valência. Neste sentido, calos nucelares de laranja 'Valência', procedentes do meio de multiplicação foram mantidos no mesmo meio líquido em agitador orbital a $200 \mathrm{rpm}$ durante $24 \mathrm{~h}$ e posteriormente peneirados de acordo com os tratamentos. As peneiras utilizadas apresentaram malhas de $150 \mu \mathrm{m}$ (P1), $300 \mu \mathrm{m}$ (P2) e $600 \mu \mathrm{m}$ (P3). Além do efeito das peneiras também foram observados os efeitos de exposição ao frio $\left(4^{\circ} \mathrm{C}\right.$ por quatro semanas, ausência de luz) e dessecação $\left(27^{\circ} \mathrm{C}\right.$, em placas de Petri na ausência de meio de cultura, seis dias, ausência de luz), sendo posteriormente mantidos em B.O.D., a $26 \pm 1^{\circ} \mathrm{C}$ e intensidade luminosa de 300 lux. Os resultados obtidos permitiram concluir que em relação ao desenvolvimento e produção de embriões somáticos o fator peneira foi superior ao fator estresse na freqüência embriogênica. $O$ desenvolvimento de embriões somáticos em Citrus sinensis ocorre mais eficientemente a partir de agrupamentos celulares de tamanhos específicos. 


\title{
COMPARATIVE ANALYSIS OF SOMATIC EMBRYOGENESIS IN CitruS sinensis, var. Valencia, and Citrus limonia, var. Rangpur lime
}

\author{
Author: JOANNE NEVES MORAES
}

Adviser: Prof ${ }^{a}$. Dr ${ }^{a}$. ADRIANA PINHEIRO MARTINELLI RODRIGUEZ

\section{SUMMARY}

Somatic embryogenesis is an alternative technique with potential application for clonal propagation of plants, and an excellent tool for basic studies and analysis of the molecular and biochemical events that occur during embryogenesis. However, although many studies have been done, the factors that control somatic embryogenesis are not completely understood. Thus, the present study proposes to evaluate aspects of somatic embryogenesis of two citrus species, which differ in efficiency for the production of somatic embryos. Initially, a comparison of the embryogenic process was done in terms of structural and histochemical analysis and evaluation of the expression of the gene AtSERK1 in callus cultures through in situ hybridization. For the experiments, callus cultures obtained from nucelli of two species, Citrus sinensis L. Osbeck, cv. Valencia, and Citrus limonia Osbeck, cv. Rangpur lime were used for anatomical and histochemical observations, callus samples from cultures in multiplication medium, in embryo induction medium, and somatic embryos in different stages of development were collected. Callus and embryo samples were also collected for analysis of gene expression through in situ hybridization. The anatomical and histochemical analysis showed differences between 
Rangpur lime and Valencia callus cultures. The in situ hybridization results evidenced the expression of the gene AtSERK1 in cultures of both citrus species, and also in both culture conditions: multiplication medium, with sucrose, and embryo induction medium, with maltose, indicating that the embriogenic potential is already installed in the callus cultures in multiplication medium. The results also lead to the conclusion that the gene is conserved between Arabidopsis thaliana and Citrus. Experiments aiming to synchronize the somatic embryogenesis formation in C. sinensis, cv. Valencia, were installed testing the effect of cold, desiccation and cell cluster size on somatic embryo formation. For that, callus cultures of 'Valência' sweet orange were cultivated in liquid medium in an orbital shaker, at $200 \mathrm{rpm}$, for $24 \mathrm{~h}$, and sieved through the following screens: $150 \mu \mathrm{m}$ (P1), $300 \mu \mathrm{m}$ (P2) and $600 \mu \mathrm{m}$ (P3). The cell aggregates were then exposed to cold $\left(4^{\circ} \mathrm{C}\right.$, for four weeks, in the dark) and desiccation $\left(27^{\circ} \mathrm{C}\right.$, in Petri plates without culture medium, six days, in the dark) treatments, and cultured in incubators at $26 \pm 1^{\circ} \mathrm{C}$ and 300 lux of light intensity. The results lead to the conclusion that the separation of cultures in clusters of different sizes and the stress treatments were effective for synchronization and embryogenesis frequency. The size of cell clusters was the most important factor. 


\section{INTRODUÇÃO}

As frutas cítricas ocupam o primeiro lugar em volume de produção em fruticultura, de acordo com as estatísticas sobre agricultura mundial. $\mathrm{O}$ Brasil ocupa posição de destaque na citricultura mundial, sendo o maior produtor de laranjas e o maior exportador de suco cítrico concentrado e congelado do mundo (FAO, 2003). Apesar disso, diversos problemas têm ameaçado a citricultura nacional nos últimos anos, destacando-se o baixo potencial genético das variedades e os problemas fitossanitários. Dentre estes, o avanço da clorose variegada dos citros (CVC), do cancro cítrico, do declínio, o surgimento da morte súbita, entre outros, têm contribuído para a redução da produtividade dos pomares. De tal modo, percebe-se a necessidade do desenvolvimento e melhoramento de variedades, especialmente no que diz respeito a resistência a doenças, produtividade e qualidade dos frutos.

Uma das alternativas para minimizar os problemas fitossanitários é o melhoramento genético. Porém, o melhoramento genético de espécies cítricas por meio de métodos tradicionais defronta-se com muitas dificuldades originadas da complexibilidade de sua natureza biológica, que dificultam a sua aplicação, tais como o longo período juvenil, a poliembrionia nucelar, a auto e interincompatibilidade e a alta heterozigose (Machado, 1997).

A utilização de técnicas biotecnológicas tem se mostrado uma alternativa importante para dirimir essas limitações, além de ser uma ferramenta auxiliar em estudos dos processos morfológicos, citológicos e fisiológicos.

A cultura de tecidos pode efetivamente contribuir para a obtenção

de plantas com características agronômicas desejáveis, utilizando-se de 
técnicas como a micropropagação, hibridação somática, ou transformação genética associada a programas de melhoramento genético. A técnica de micropropagação consiste na obtenção em larga escala de plantas (clones), em tempo reduzido. A hibridação somática possibilita a redução dos problemas de incompatibilidade em cruzamentos interespecíficos, permitindo a obtenção de plantas híbridas, combinando-se o genoma de duas espécies com características desejáveis. O processo de transformação genética possibilita a introdução de gene(s) exógeno(s) no genoma da espécie de interesse. Contudo, esses métodos necessitam como principal condição a utilização de metodologias eficientes para a regeneração de plantas in vitro como a organogênese ou a embriogênese somática.

A embriogênese somática apresenta um grande potencial na propagação clonal de espécies, sendo bastante estudada em Citrus spp. (Kochba et al., 1972; Kochba et al., 1978; Kochba et al., 1982; Gmitter Junior \& Moore, 1986; Moore, 1985; Cabasson et al., 1995; Tomaz et al., 2001). Existe, porém, uma grande variação entre os protocolos e os resultados obtidos, observando-se que os resultados são dependentes principalmente do genótipo.

A falta de conhecimento dos fatores que controlam a embriogênese somática e a assincronia do desenvolvimento de embriões somáticos são responsáveis por sua reduzida aplicação comercial, porém muitas pesquisas têm sido dirigidas para um maior entendimento deste processo (Pedroso \& Pais,1995).

A compreensão do processo de embriogênese somática pode colaborar efetivamente para a sua otimização. Zimmerman (1993) afirma que a embriogênese já foi extensivamente descrita, através de diferentes técnicas histológicas, porém existe ainda uma carência em termos de estudos moleculares e bioquímicos do processo, que tem sido dificultado pela localização do embrião zigótico.

Estudos da embriogênese em nível molecular, analisando-se a expressão de genes relacionados ao desenvolvimento embrionário, vêm sendo 
intensamente realizados, utilizando-se plantas modelo como Arabidopsis thaliana, e em menor escala milho (Zea mays) e arroz (Oryza sativa). Esses estudos podem ser importantes ferramentas para o entendimento do processo embriogênico, assim como para a compreensão de falhas do desenvolvimento de embriões somáticos em Citrus spp.

Desta forma, o objetivo do presente trabalho foi estudar dois sistemas com diferentes graus de eficiência embriogênica, analisando-se características histológicas, histoquímicas e de expressão gênica. Através destas análises pretendeu-se ampliar o conhecimento sobre um sistema altamente embriogênico, comparado a um sistema com baixa capacidade embriogênica. Pretendeu-se, também, avaliar a viabilidade de utilização de sondas de alguns genes marcadores da embriogênese zigótica em Arabidopsis, no processo de embriogênese somática a partir de calos de citros. Em seguida, apresenta-se uma revisão bibliográfica relacionada a embriogênese somática e os parâmetros estudados nesta dissertação. Posteriormente, apresentam-se dois capítulos redigidos em forma de trabalhos científicos.

No primeiro deles, enfocou-se um estudo da embriogênese somática utilizando-se análises histológicas, histoquímicas e de expressão gênica. No segundo, apresentam-se dados relativos ao efeito do estresse e agrupamentos celulares na sincronização da embriogênese somática de Citrus sinensis, var. Valência. Por fim, apresentam-se as conclusões gerais dos trabalhos desenvolvidos nesta dissertação. 


\section{REVISÃO DE LITERATURA}

Os citros são originários do sudeste da Ásia, estendendo-se desde o sul da China, nordeste da Índia, Nova Guiné até a Austrália (Spiegel-Roy \& Goldschmidt, 1996; Simão, 1998), sendo atualmente cultivados em todo o mundo, em países tropicais e subtropicais entre as latitudes $40^{\circ} \mathrm{N}$ e $40^{\circ} \mathrm{S}$ (Davies \& Albrigo, 1994).

O grupo das plantas cítricas pertence à família Rutaceae e é compreendido de seis gêneros incluindo Citrus, Clymenia, Eremocitrus, Fortunella, Microcitrus e Poncirus. Dentre estes, o gênero Citrus é o mais importante economicamente (Gosal et al., 1995).

A laranja é a responsável pelo salto observado na fruticultura brasileira nas duas últimas décadas. O Brasil é o maior produtor de laranjas do mundo, com uma produção de 17.993.000 toneladas métricas, seguido pelos E.U.A. e México, sendo que o Estado de São Paulo produz mais de $80 \%$ do total. Por outro lado, embora o Brasil seja grande produtor da fruta fresca, é o setor de suco concentrado que vem crescendo muito, sendo que o Brasil é o maior produtor mundial de suco concentrado, com 1.269 .000 toneladas métricas (FNP Consultoria \& Comércio, 2003).

Vários fatores impedem o aumento da produtividade da cultura, como a susceptibilidade das variedades a diversas doenças, pragas e anormalidades fisiológicas, e ainda, à baixa adaptação às condições edafoclimáticas (Cristofani, 1991; Machado, 1997; Fundecitrus, 2003).

Os programas tradicionais de melhoramento de citros foram conduzidos intensamente nos Estados Unidos, sendo significativamente 
representados pelos trabalhos de W. T. Swingle, com obtenção de vários híbridos interespecíficos. No Brasil, o melhoramento de citros tem sido muito mais uma atividade de coleta, manutenção e seleção massal de variantes espontâneos (Machado, 1997). Entretanto, o melhoramento das espécies cítricas por meio dos métodos convencionais tem sido limitado por fatores inerentes à sua biologia. Sendo assim, a despeito da grande importância da citricultura no Brasil, o setor poderia se beneficiar de novas tecnologias para incrementar ganhos na produtividade.

Neste sentido, a biotecnologia apresenta importantes instrumentos que podem auxiliar no processo de melhoramento genético das espécies cítricas. Segundo Ollitrault \& Luro (1995), a cultura de tecidos, a biologia molecular, a fusão de protoplastos e a transformação genética já são ferramentas incorporadas em diversos programas de melhoramento genético de citros. As técnicas biotecnológicas podem ser aplicadas de formas distintas no desenvolvimento de cultivares superiores de plantas, em uma ou outra etapa do melhoramento.

Os primeiros trabalhos de cultura de tecidos de citros iniciaram-se na década de 50. Um dos primeiros enfoques foi a obtenção de embriões nucelares in vitro a partir das espécies monoembriônicas com a finalidade de produzir plantas isentas de viroses. Em seguida, intensificou-se a obtenção de calos nucelares pela possibilidade de se conseguir embriões somáticos em grande quantidade a partir desses calos (Cristofani, 1991).

Atualmente, várias técnicas de cultura de tecidos em citros encontram-se descritas na literatura, como o cultivo de calos (Mourão Filho \& Grosser, 1992; Oliveira et al., 1994a), células em suspensão (Oliveira et al., 1994b; Cabasson et al., 1995) e protoplastos (Kobayashi \& Ohgawara, 1998; Grosser \& Gmitter Junior, 1990a; Mendes-da-Glória et al., 1997), principalmente com o objetivo de facilitar a manipulação genética através de hibridação somática (Grosser \& Gmitter Junior, 1990b), e mais recentemente, a 
transformação genética via organogênese (Hiramatsu et al., 1994; Penã et al., 1995; Mendes et al., 2002; Almeida et al., 2002).

Estas técnicas vêm permitindo novas possibilidades para o entendimento dos processos morfogenéticos e o melhoramento genético em Citrus. De acordo com Grosser \& Gmitter Junior (1990a), o sucesso no melhoramento dos citros será maior com o desenvolvimento de programas que combinem métodos convencionais de melhoramento com novas biotecnologias.

\subsection{Embriogênese Somática em Citros}

A embriogênese somática é definida como o processo pelo qual células haplóides ou somáticas desenvolvem-se formando estruturas semelhantes ao embrião zigótico, e posteriormente originam uma planta, sem que ocorra fusão de gametas (Thorpe, 1995; Guerra et al., 1999). Contudo, este processo não é restrito a condições in vitro, já que a apomixia ou embriogênese nucelar, formação assexuada de embriões, ocorre comumente na natureza, tendo como exemplo variedades poliembriônicas do gênero Citrus. Esses embriões, denominados apomíticos, são geneticamente iguais à planta mãe, permitindo a perpetuação de populações clonais por meio da semente.

De acordo com Torres et al. (1999), a formação de embriões somáticos foi observada pela primeira vez, independentemente, por Steward, em 1958, e por Reinert, em 1959, em cultura de calos de cenoura. Desde então, este processo tem sido considerado importante, tanto como via de regeneração de plantas in vitro, quanto como modelo para estudos básicos relacionados à fisiologia e morfogênese do embrião de plantas (Zimmerman, 1993; Yeung, 1999).

O padrão de desenvolvimento de um embrião somático em dicotiledôneas apresenta muitas características morfológicas similares às do embrião zigótico. Zimmerman (1993) afirma que o desenvolvimento normal de 
embriões a partir de células somáticas comprova que o programa genético para embriogênese está totalmente contido na célula.

Segundo Haccius (1978), os embriões somáticos passam pelos estádios de desenvolvimento embrionários: globular, cordiforme, torpedo, e cotiledonar, semelhantes ao padrão de desenvolvimento do embrião zigótico. Além disso, o embrião somático caracteriza-se pela bipolaridade, constituída de ápice caulinar e radicular, e um sistema vascular fechado sem conexão com os tecidos do explante inicial.

Os embriões somáticos in vitro podem ser formados a partir de dois padrões básicos de embriogênese, direto ou indireto. Porém a grande maioria dos sistemas de embriogênese somática ocorre pela via indireta. De acordo com Sharp (1980), a embriogênese somática direta ocorre a partir do explante, o qual possui células programadas para a diferenciação ("preembryogenic determined cells" - PEDC) e formação dos embriões somáticos. $\mathrm{Na}$ embriogênese somática indireta, a formação dos embriões somáticos envolve a desdiferenciação celular, proliferação de calos, e a diferenciação de células embriogênicas ("induced embryogenic determined cells" - IEDC).

As células embriogênicas pré-determinadas (PEDCs) necessitam de pequena indução exógena de reguladores de crescimento para a divisão celular e expressão da embriogênese pois, sendo pré-determinadas, sua exposição a reguladores de crescimento permite à embriogênese ocorrer. As células induzidas à determinação embriogênica (IEDCs) precisam de reguladores de crescimento para reentrar em mitose e determinar o estado embriogênico dos calos (Sharp, 1980; Gosal et al., 1995).

Calos podem ser definidos como massas de células em diferentes estádios de diferenciação e, conseqüentemente, com diferentes graus de determinação, os quais podem ser induzidos por estímulos ambientais ou químicos, e reprogramados, adquirindo novas competências morfogenéticas (Guerra et al., 1999). 
A embriogênese somática já foi relatada em várias espécies cítricas, principalmente a partir de calos originados do cultivo de óvulos (Button \& Bornman, 1971; Kochba et al., 1972; Oliveira et al., 2001; Benedito et al., 2000) e nucelos (Gmitter Junior \& Moore, 1986, Oliveira et al., 1994a, b; Tomaz et al., 2001), empregando-se diferentes substâncias no meio de cultura. Entretanto, diferentes resultados foram obtidos em termos de conversão de plantas.

Segundo Spiegel-Roy \& Kochba (1980) e Moore (1985), os fatores que têm maior influência sobre a indução de calos nucelares embriogênicos são as condições do ambiente em que a plantas se desenvolvem, o genótipo, a idade dos explantes, os componentes do meio de cultura e as condições de cultivo.

Ao contrário do que ocorre em outras espécies, a presença de auxinas, citocininas ou giberelinas no meio suprimem a embriogênese somática em citros, devido aos elevados índices de reguladores de crescimento endógenos (Gosal et al., 1995). Este efeito tem sido compensado pela utilização de substâncias inibidoras de auxinas, bem como inibidores de giberelina e citocinina, que mostraram efeito positivo no estímulo à formação de embriões somáticos (Kochba \& Spiegel-Roy, 1977; Kochba et al., 1978; Kobayashi et al., 1978). Além disso, alguns autores obtiveram embriogênese somática em citros utilizando meio de cultura livre de reguladores de crescimento (Gosal et al., 1995).

Um dos fatores mais importantes para a obtenção de embriogênese somática em calos de citros, porém, é a fonte de carbono. Diversos autores têm estudado o efeito de diferentes tipos e concentrações de carboidratos no estímulo à embriogênese (Kochba et al., 1982; Cabasson et al., 1995; Benedito et al., 2000; Tomaz et al., 2001; Ricci et al., 2002).

Estudos realizados recentemente por Benedito et al. (2000) e Tomaz et al. (2001), avaliaram diferentes fontes de carboidratos para a obtenção de embriões somáticos em diferentes genótipos de citros, a partir de 
culturas de calos provenientes de protoplastos, ou de nucelos. Estes observaram que as alterações no tipo de carboidrato promovem modificações no comportamento das culturas de calos, em relação à embriogênese somática, dependendo do genótipo. Tomaz et al. (2001) observou ainda que as culturas de calos de laranja 'Valência' (Citrus sinensis L. Osbeck) são altamente embriogênicas, enquanto que as linhagens de calos de limão 'Cravo' (Citrus limonia L. Osbeck) demonstraram baixo potencial embriogênico, mesmo utilizando-se diferentes carboidratos no meio de cultura.

O meio de cultura normalmente utilizado para o cultivo de calos embriogênicos é composto por sais e vitaminas de Murashige \& Tucker (1969), suplementado com $50 \mathrm{~g} \mathrm{~L}^{-1}$ de sacarose e $500 \mathrm{mg} \mathrm{L}^{-1}$ de extrato de malte (Kochba et al., 1972; Grosser \& Gmitter Junior, 1990a; Ling \& Iwamasa, 1994). $\mathrm{Na}$ embriogênese de citros têm sido relatados efeitos benéficos do extrato de malte. Porém, devido à constituição complexa dessa substância, ainda se desconhece o componente responsável por esse efeito (Oliveira et al., 1994a).

Perez et al. (1998) relataram ausência de sincronismo celular durante o desenvolvimento de embriões somáticos em citros. Diversos autores demonstram que períodos de estresse durante o cultivo in vitro podem promover aumentos nas taxas de indução, maturação e germinação de embriões somáticos (Wetzstein et al., 1990; Lecouteux et al., 1993; Misra et al., 1993; Dronne et al., 1997; Lee et al., 2001; Ikeda-Iwai et al., 2003).

Anandarajah \& McKersie (1990) e Lecouteux et al. (1993) relatam a influência da temperatura no estímulo à embriogênese somática. Neste sentido, o efeito do frio na indução e na germinação de embriões foi descrito em inúmeros trabalhos. De acordo com Janeiro et al. (1995), o armazenamento a frio de culturas in vitro pode ser aplicado como pré-tratamento para a promoção da maturação e da capacidade de germinação de embriões somáticos em diferentes espécies.

Além de estresse provocado pelo frio, períodos de dessecação na cultura podem melhorar a taxa de germinação e o número de embriões 
somáticos em cenoura. Lee et al. (2001) sugerem que a dessecação dos calos inibe a proliferação normal de células não diferenciadas, estimulando desta forma, a produção de embriões somáticos.

A separação de agregados celulares também é citada como uma alternativa na sincronização do desenvolvimento de embriões somáticos, tornando as culturas mais homogêneas em relação ao tamanho dos agregados, o qual age também acelerando a capacidade de diferenciação das massas próembriogênicas em embriões somáticos (Merkle et al., 1990).

Segundo Yeung (1999), o conhecimento anatômico do material, através de análises histológicas, vem auxiliar no entendimento da organização e mudanças que ocorrem durante a morfogênese in vitro, bem como permite distinguir a origem das estruturas formadas $e$ as falhas durante $o$ desenvolvimento in vitro. Além disso, pode explicar os problemas relativos à conversão dos embriões somáticos em plantas. Em citros, a caracterização histológica dos embriões somáticos de duas linhagens de tangerina 'Cleópatra' e de limão 'Cravo', permitiu atribuir a baixa ocorrência de desenvolvimento do embrião somático à ausência de histodiferenciação (Tomaz et al., 2001).

Apesar dos avanços verificados no estudo da embriogênese somática, ainda é limitada a compreensão dos estímulos e condições necessárias para a indução e controle desse processo. A utilização do processo de embriogênese somática para fins tecnológicos depende do domínio preciso da fisiologia do desenvolvimento (Guerra et al.,1999).

\subsection{Expressão Gênica e Embriogênese}

O termo desenvolvimento refere-se ao crescimento integrado das várias partes de um ser pluricelular envolvendo basicamente os processos de divisão, expansão e diferenciação celular e a conseqüente formação de tecidos, órgãos e sistemas. Em plantas, parte desse desenvolvimento se processa durante uma etapa denominada embriogênese (Peres, 2002). 
O processo embriogênico de plantas se inicia após a fertilização da célula-ovo, que sofre repetidas divisões celulares, seguidas de alongamento e diferenciação para formar um embrião multicelular. A primeira divisão geralmente é assimétrica, o que resulta em duas células-filhas, uma apical e outra basal, com diferentes identidades. A célula apical sofre várias divisões formando o embrião propriamente dito, enquanto a célula basal se divide várias vezes para formar o suspensor. O período de divisão celular é rápido, e permite que a célula-ovo se divida em um grupo de células menores. Entre cada divisão não há aumento de massa celular, pois o ciclo durante as clivagens consiste simplesmente de fases de replicação do DNA, mitose e divisão celular, sem nenhum estágio intermediário de alongamento. Toda informação genética para o desenvolvimento embrionário, e da planta, está contida no genoma do zigoto (Wolpert et al., 2000).

Durante o desenvolvimento, o embrião forma o eixo embrionário e um ou dois cotilédones, os quais possuem diferentes destinos de desenvolvimento. O eixo embrionário contém os meristemas caulinar e radicular, a partir dos quais a planta madura se formará após a germinação. $O$ cotilédone, por sua vez é um órgão responsável pela síntese e armazenamento das reservas utilizadas pela plântula, e que senesce após a germinação (Goldberg et al., 1989). Portanto, a embriogênese em plantas é um processo complexo e altamente organizado, sendo regulado por vários grupos de genes (Jürgens, 1995). O grande número de genes expressos em embriões de plantas demonstra uma complexidade em nível molecular que não é evidente a partir de uma caracterização anatômica (Goldberg et al., 1989).

A expressão de genes em regiões e/ou em momentos distintos pode levar a alterações importantes, ou mesmo impedir o desenvolvimento embrionário. Mordhorst \& Lorz (1993) constataram que o uso de glutamina como única fonte de nitrogênio causou inibição do eixo embrionário em cevada. Esta inibição, segundo Stirn et al. (1995), estava relacionada à expressão, na 
fase inicial do desenvolvimento do embrião, de genes que normalmente se expressam após a formação do eixo embrionário.

Muitos genes estão envolvidos na regulação do desenvolvimento (Buchanan et al., 2000). Conseqüentemente, o entendimento de como esses genes controlam o comportamento celular pode facilitar a compreensão do processo de desenvolvimento. A identificação e análise de genes específicos do processo embriogênico, ou de uma fase específica desse processo é, por conseguinte, altamente desejável para um melhor entendimento dos mecanismos moleculares relacionados ao desenvolvimento do embrião em plantas (Jürgens, 1995).

A capacidade de obtenção de embriões a partir de células somáticas, morfologicamente normais e com desenvolvimento semelhante ao processo zigótico, é uma característica única de plantas (Zimmerman, 1993). Morfologicamente, as mudanças que ocorrem durante a embriogênese somática são similares àquelas que ocorrem em embriões zigóticos, porém os embriões somáticos não se desenvolvem dentro de sementes (Crouch, 1982). A embriogênese somática é uma importante via para regeneração de plantas e pode ser utilizada como um sistema modelo para entender os eventos morfogenéticos e a regulação da expressão gênica necessária para o desenvolvimento da embriogênese de plantas superiores (Zimmerman, 1993).

A habilidade das células diferenciadas de plantas formarem embriões em cultura sugere que o zigoto não é o único responsável pelos fatores exigidos para programar o início de desenvolvimento das plantas, ou que as células somáticas retêm o potencial para expressar o programa da expressão de genes do zigoto, sob condições adequadas. Embora a identidade dos fatores e sinais responsáveis por ativar uma via embriogênica ainda não seja conhecida, a habilidade de células somáticas regenerarem embriões em cultura implica que elas possuem um completo grupo de genes que retêm o potencial para programar todos os estados diferenciados das plantas (Goldberg et al., 1989). De acordo com Crouch (1982), grupos de genes ativos em células 
de cotilédone de embriões zigóticos estão ativos também em células análogas durante a embriogênese somática.

São muitos os fatores envolvidos na expressão morfogenética, desde a interação célula-célula até a participação de genes específicos. As plantas são responsivas a fatores do meio, mas é a expressão gênica que determina onde e como ocorre o desenvolvimento, concluindo-se assim, que o desenvolvimento sobrevém em resposta a instruções contidas nos genes (Fosket, 1994).

Segundo Wolpert et al. (2000), os genes são ativados e desativados durante o desenvolvimento, e os padrões de expressão destes estão sendo alterados continuamente. Para que se entenda como a expressão gênica está guiando o desenvolvimento, é fundamental conhecer precisamente onde e quando determinados genes estão ativos.

O uso da hibridização in situ permite a localização da expressão de genes, através do uso de sondas, tanto em cortes histológicos, como em materiais inteiros, de tamanho bastante reduzido. Através desta técnica pode-se detectar o mRNA transcrito a partir de um gene. Se uma sonda de RNA antisense possui uma seqüência complementar a uma porção do mRNA transcrito na célula, ela hibridizará, ou seja, fará um pareamento estável, com aquele mRNA. A sonda pode ser marcada de várias maneiras: com um isótopo radioativo, um corante fluorescente ou uma enzima para localização histoquímica, que permitirá a sua detecção (Wolpert et al., 2000).

Estudos moleculares com relação ao desenvolvimento de embriões, têm sido realizados utilizando-se principalmente a crucífera Arabidopsis thaliana como modelo, e em menor escala em milho e arroz. O uso de Arabidopsis no detalhamento genético do processo embriogênico se deve ao fato dessa planta possuir padrões regulares e previsíveis de divisões celulares e uma variedade de mutantes para diferentes fases do desenvolvimento (Vroemen, 1998; Buchanan et al., 2000). Além disso, Arabidopsis tem pequeno 
tamanho, ciclo de vida curto, genoma pequeno e fácil manipulação em laboratório (Fosket, 1994; Buchanan et al., 2000).

Apesar dos avanços constatados no estudo da embriogênese somática, a compreensão dos estímulos e das condições necessárias para a indução e o controle desse processo ainda são muito limitadas, existindo uma carência de estudos comparativos relacionando a expressão e a análise molecular de genes envolvidos nos processos de embriogênese somática (Vroemen, 1998). Uma questão fundamental é saber se os eventos que induzem a formação da embriogênese somática diferem significativamente daqueles que originam os embriões zigóticos. Neste sentido, alguns estudos vêm sendo publicados mais recentemente. Genes como Leafy Cotyledon 1 (LEC1), mutantes dos genes pickle (pkl), primordia timing ( $p t)$ e clavata, e muitos outros estão sendo estudados e parecem estar envolvidos na transição da célula somática para embriogênica. A expressão ectópica do gene LEC1 resultou na embriogênese somática espontânea em folhas (De Vries, 1998).

Muitos genes relacionados à embriogênese zigótica em $A$. thaliana já foram identificados e clonados. Dentre esses genes, alguns têm despertado o interesse em estudos visando a avaliação da conservação gênica de várias plantas, tanto em embriogênese zigótica, como em somática.

O gene SOMATIC EMBRYO RECEPTOR KINASE (SERK) é formado por uma família de genes que controla a transição de uma célula somática em embriogênica. SERK foi identificado por Schmidt et al. (1997) em cenora, durante a embriogênese zigótica até o estágio globular, e em células competentes que se desenvolveram em embriões somáticos. O gene SERK1 também foi isolado de Arabidopsis, sendo expresso nas células do saco embrionário e durante a embriogênese zigótica até o estágio cordiforme, e em cultura de células durante o estabelecimento da embriogênese somática (Hecht et al., 2001).

Baudino et al. (2001) isolaram e caracterizaram dois membros da família SERK, os genes ZmSERK1 e ZmSERK2, em milho, que se 
expressaram em cultura de calos embriogênicos e não embriogênicos. O gene SERK é considerado um marcador de células competentes, precursoras de células embriogênicas que se desenvolverão em embriões somáticos. Hecht et al. (2001) afirmaram que o gene AtSERK1 aumenta a competência embriogênica em cultura de células de Arabidopsis.

O gene SHOOT MERISTEMLESS está envolvido no padrão apical-basal de desenvolvimento. Este gene codifica uma classe de proteínas semelhante ao KNOTTED1 (Long \& Barton, 1998), que codifica uma proteína homeodomínio que possui função no meristema apical (Toonen, 1997).

O gene Arabidopsis thaliana MERISTEM LAYER 1(AtML1) expressa-se exclusivamente na epiderme de embriões em desenvolvimento e em meristemas apicais. O padrão de expressão diferencial do gene AtML1 em células específicas do pró-embrião sugere um papel regulador na formação do padrão apical-basal do embrião (Lu et al., 1996; Sessions et al., 1999).

A função da família do gene YABBY é a especificidade abaxial de células destinadas à produção de órgãos laterais pelo meristema apical e floral. Os componentes da família do gene YABBY são, atualmente, os únicos fatores conhecidos responsáveis pela especificação do destino das células abaxiais (Siegfried et al., 1999; Bowman, 2000; Kumaran et al., 2002).

Vários outros genes já foram relatados como marcadores específicos da embriogênese em plantas. Segundo Stirn et al. (1995) estes genes marcadores podem ser utilizados para caracterizar culturas embriogênicas, bem como elucidar os mecanismos moleculares de diferenciação celular. 


\section{ANÁLISE COMPARATIVA DA EMBRIOGÊNESE SOMÁTICA DE Citrus sinensis E Citrus limonia}

\section{Resumo}

A embriogênese somática em citros já foi obtida em várias espécies e estudos das condições de cultivo foram extensivamente realizados, porém, há ainda carência de um melhor entendimento do processo embriogênico não somente para citros, mas para outras espécies. Neste trabalho propomos o estudo da embriogênese somática em dois sistemas com diferentes graus de eficiência através de análises histológicas, histoquímicas, e uma abordagem molecular, estudando-se a expressão in situ do gene AtSERK1 relacionado ao processo embriogênico em $A$. thaliana. Calos embriogênicos provenientes de nucelos de laranja 'Valência' (Citrus sinensis) e limão 'Cravo' (Citrus limonia) foram subcultivados a cada 4 semanas em meio sólido EME, suplementado com $50 \mathrm{~g} \mathrm{~L}^{-1}$ de sacarose e $0,5 \mathrm{~g} \mathrm{~L}^{-1}$ de extrato de malte. A partir desses calos, para expressão da embriogênese somática, utilizou-se o mesmo meio de cultura, porém trocando-se a fonte de carboidrato para $13,4 \mathrm{~g} \mathrm{~L}^{-1}$ de maltose. Amostras de calo em meio de multiplicação, com sacarose, calo em meio de obtenção de embriões, com maltose, e embriões somáticos foram coletados para análises anatômicas, histoquímicas e de expressão gênica utilizando-se a técnica de hibridização in situ. Os resultados obtidos evidenciaram diferenças anatômicas entre os calos das duas linhagens de citros, sendo que as culturas de calos de laranja 'Valência' demonstraram ser mais embriogênicas. Os calos das duas linhagens de citros expressaram o 
gene AtSERK1, tanto em meio com sacarose, quanto em meio com maltose, indicando que as duas espécies possuem células competentes e com potencial embriogênico, mesmo em condições de multiplicação de calos.

\section{Summary}

Citrus somatic embryogenesis was obtained in several species and many studies have been done. However, a better understanding of the process is still needed for somatic embryogenesis in general. Here we propose a study comparing two embryogenic systems with different efficiency levels, through histological and histochemical analysis and also emphasizing a molecular approach, by studying the in situ expression of the AtSERK gene. Nucellar callus from 'Valencia' sweet orange (Citrus sinensis) and 'Rangpur' lime (Citrus limonia) were subcultured at 4-week intervals in multiplication medium, consisting of EME solid medium supplemented with $50 \mathrm{~g} \mathrm{~L}^{-1}$ sucrose and $0.5 \mathrm{~g}$ $\mathrm{L}^{-1}$ malt extract. To obtain somatic embryos, callus was transferred to the same medium with maltose $\left(13.4 \mathrm{~g} \mathrm{~L}^{-1}\right)$, replacing sucrose as the carbohydrate source. Samples of callus in multiplication medium, with sucrose, medium for embryo development, with maltose, and samples of embryos in various developmental stages were collected for anatomical, histological and gene expression analysis, through in situ hybridization. The results evidenced anatomical differences between the two callus lines of citrus, with 'Valencia' sweet orange callus showing higher embryogenic efficiency compared to 'Rangpur' lime. Callus cultures from both citrus lines expressed the AtSERK gene both, in multiplication medium, with sucrose, and in embryo development medium, with maltose, indicating that both species have the embryogenic potential already in callus multiplication medium conditions.

\subsection{Introdução}


A embriogênese somática é um caso característico de morfogênese, onde a partir de tecidos do explante (embriogênese direta) ou do calo (embriogênese indireta), formam-se estruturas semelhantes aos embriões zigóticos (Floh \& Handro, 1985).

A capacidade de obtenção de embriões a partir de células somáticas, os quais possuem desenvolvimento semelhante ao processo zigótico é uma característica única de plantas (Zimmerman, 1993).

De acordo com Wetzstein et al. (1990), a embriogênese somática tem sido induzida em várias espécies oferecendo novos caminhos para o melhoramento de plantas. Contudo, muitos sistemas de embriogênese somática possuem fatores limitantes comuns, como a baixa freqüência embriogênica, e baixos níveis de conversão dos embriões somáticos.

A embriogênese somática é considerada uma das técnicas mais eficientes para a obtenção de avanços genéticos em espécies cítricas, pois permite a obtenção de plantas a partir de culturas de calos geneticamente transformadas, culturas de protoplastos ou hibridação somática (Gmitter Junior et al., 1990).

Estudos visando a obtenção de embriões somáticos já foram relatados em várias espécies e variedades de citros, com diferentes resultados em termos de conversão em plantas.

Segundo Yeung (1999), o conhecimento estrutural das culturas através da análise histológica pode explicar os problemas relativos à conversão dos embriões somáticos em plantas. Além disso, a análise histológica auxilia o entendimento da organização e mudanças que ocorrem durante a morfogênese in vitro, bem como permite distinguir a origem de estruturas formadas e falhas durante o desenvolvimento in vitro.

O detalhamento genético do processo embriogênico vem sendo estudado principalmente em Arabidopsis thaliana, como modelo. Entretanto, pesquisas envolvendo aspectos moleculares do desenvolvimento de embriões somáticos são ainda muito escassas (Vroemen, 1998). 
Com o objetivo de estudar comparativamente dois sistemas com diferentes graus de eficiência embriogênica, este trabalho propõe analisar características histológicas, histoquímicas e de expressão gênica de Citrus sinensis, var. Valência, e Citrus limonia, var. limão Cravo.

\subsection{Material e Métodos}

\subsubsection{Cultivo In Vitro}

Calos nucelares de $C$. sinensis e C. limonia, obtidos de acordo com o procedimento descrito por Benedito et al. (2000), vêm sendo mantidos no Laboratório de Biotecnologia Vegetal, CENA/USP, há cerca de 8 anos. As culturas de calos foram multiplicadas em meio EME (Grosser \& Gmitter Junior, 1990a), suplementado com $146 \mathrm{mM}$ de sacarose $\left(50 \mathrm{~g} \mathrm{~L}^{-1}\right)$ e extrato de malte $\left(0,5 \mathrm{~g} \mathrm{~L}^{-1}\right)$, mantidas no escuro, à temperatura de $27 \pm 0,1^{\circ} \mathrm{C}$, e subcultivadas a cada 4 semanas.

Para a obtenção de embriões somáticos, calos em meio de multiplicação (aprox. $50 \mathrm{mg}$ ) foram transferidos para o meio de cultura EME sólido, suplementado com $37 \mathrm{mM}$ de maltose $\left(13,7 \mathrm{~g} \mathrm{~L}^{-1}\right)$ e extrato de malte $(0,5$ $\mathrm{g} \mathrm{L}^{-1}$ ), conforme Tomaz et al. (2001). Para melhor distribuição dos calos no meio de cultura foram utilizadas 12 gotas do mesmo meio, porém líquido, facilitando a desagregação e distribuição do calo em sua superfície. As culturas foram mantidas em BOD, com intensidade luminosa de 300 lux, fotoperíodo de $12 \mathrm{~h}$ e temperatura de $26 \pm 0,5^{\circ} \mathrm{C}$.

\subsubsection{Análises Anatômicas e Histoquímicas}

Amostras de calos das duas espécies, cultivados em meio de multiplicação (sacarose) e em meio para obtenção de embriões somáticos (maltose), bem como embriões somáticos de laranja 'Valência' nas diferentes 
fases de desenvolvimento e algumas estruturas que se desenvolveram em culturas de limão 'Cravo' foram coletadas e preparadas para análises anatômicas, de acordo com Rodriguez \& Wetzstein (1998). Para isto, as amostras foram fixadas por um período mínimo de $8 \mathrm{~h}$ em solução de paraformaldeído (3\%, p/v) e glutaraldeído $(2 \%, v / v)$ em cacodilato de sódio $(0,2$ M), $\mathrm{pH}$ 7,2, sob refrigeração.

Após a fixação, os tecidos foram lentamente desidratados, sob refrigeração, em uma série de (100\%) metil cellosolve, etanol, propanol e butanol. A infiltração foi realizada inicialmente em uma solução de butanol e meio de infiltração (proporção de $3: 1 ; 1: 1 ; 1: 3$ ), trocando-se a cada $2 \mathrm{~h}$, à temperatura de $4^{\circ} \mathrm{C}$, e posteriormente, em meio de infiltração (100\%), por $24 \mathrm{~h}$, ou até as amostras ficarem translúcidas e no fundo do recipiente.

Para infiltração e emblocagem das amostras utilizou-se o kit Historesin (hidroxietilmetacrilato, Leica Heidelberg) e a polimerização foi realizada à temperatura ambiente, por 2 ou 3 dias. Em seguida, foram realizados cortes seriados com espessura de $5 \mu \mathrm{m}$ em micrótomo rotativo (Leica RM2155), corados por 1 a 2 minutos em fucsina ácida $(0,1 \%)$, seguido de 1 a 2 minutos em azul de toluidina (0,05\%), conforme Feder \& O'Brien (1968) para observações estruturais. Nas análises histoquímicas, cortes seriados foram corados com azul de comassie (0,25\% em ácido acético 3\%), para observações de proteínas totais, e corados com cloreto de zinco iodado,

para amido. Posteriormente, os cortes foram observados e fotografados em microscópio óptico invertido (Zeiss Axiovert).

\subsubsection{Análise da Expressão Gênica}

\subsubsection{Extração de Plasmídeos por Lise Alcalina}

As bactérias contendo os plasmídeos pSAC61 (10-8) e pSAC-B1.4 (11-19) contendo as sondas dos clones de cDNA do gene AtSERK1, foram 
cedidos pela Dra. Valerie Hecht (Lab. Molecular Biology, Agricultural University Wageningen, Netherlands).

Para extração do DNA plasmidial as bactérias foram cultivadas em $500 \mu \mathrm{L}$ de meio LB líquido (10 $\mathrm{g} \mathrm{L}^{-1}$ triptona; $5 \mathrm{~g} \mathrm{~L}^{-1}$ extrato de levedura e $10 \mathrm{~g} \mathrm{~L}^{-}$ ${ }^{1}$ cloreto de sódio) contendo $500 \mathrm{mg} \mathrm{L}^{-1}$ ampicilina, sob agitação $( \pm 130 \mathrm{rpm})$ a $37^{\circ} \mathrm{C}$, por 8h. A suspensão bacteriana foi transferida para $5 \mathrm{~mL}$ de meio LB líquido, com ampicilina, em tubos de centrífuga de $15 \mathrm{~mL}$, cultivadas a $37^{\circ} \mathrm{C}$, sob agitação por $16 \mathrm{~h}$. Posteriormente, a suspensão bacteriana foi centrifugada durante 5 minutos, a $3000 \mathrm{rpm}$, à temperatura ambiente. O meio foi descartado e as bactérias ressuspendidas em $2 \mathrm{~mL}$ de solução I ( $25 \mathrm{mM}$ Tris- $\mathrm{HCl}$ e $10 \mathrm{mM}$ EDTA, pH 8,0). Logo depois, adicionaram-se $2 \mathrm{~mL}$ da solução II (10\% SDS e $0,2 \mathrm{M} \mathrm{NaOH}$ ) e os tubos foram mantidos em gelo, por 10 minutos. Adicionou-se $2 \mathrm{~mL}$ da solução III (3 M acetato de potássio) mantendo-se os tubos no gelo por mais 10 minutos. Posteriormente, o material foi centrifugado por 5 minutos. $\mathrm{O}$ sobrenadante foi coletado e transferido para um novo tubo, ao qual, foi adicionado o dobro do volume de etanol (100\%) gelado; misturou-se levemente, mantendo-se por $1,5 \mathrm{~h} \mathrm{a}-20^{\circ} \mathrm{C}$. Em seguida, centrifugou-se a $3000 \mathrm{rpm}\left(4^{\circ} \mathrm{C}\right.$ por $20 \mathrm{~min}$ ), o sobrenadante foi descartado e o "pellet" de DNA foi seco à temperatura ambiente, por 20 minutos. Ressuspendeu-se o DNA plasmidial em $100 \mu \mathrm{L}$ de água mili-Q estéril e armazenou-se $\mathrm{a}-20^{\circ} \mathrm{C}$.

\subsubsection{Linearização dos Plasmídeos}

A linearização do plasmídeo foi realizada para evitar uma marcação desnecessária do vetor de clonagem. Foram digeridos $2 \mu \mathrm{g}$ de DNA plasmidial em 10U. $\mathrm{L}^{-1}$ da enzima Hind III para o plasmídeo pSAC61 (10-8), e Notl para o plasmídeo pSAC-B1.4 (11-19), acrescida de $2 \mu \mathrm{L}$ do tampão da enzima num volume total de $20 \mu \mathrm{L}$. A reação ocorreu em banho-maria por $1 \mathrm{~h}$ a $37^{\circ} \mathrm{C}$. Posteriormente, o DNA plasmidial digerido foi precipitado a $-20^{\circ} \mathrm{C}$, por 10 minutos, com o dobro do volume de etanol (100\%). Em seguida, o DNA 
plasmidial foi ressuspendido em $11 \mu \mathrm{L}$ de água tratada com DEPC (Dietilpirocarbonato).

\subsubsection{Marcação da Sonda Antisense}

Para a marcação da sonda foi utilizado o Kit de marcação de sondas não-radioativas com digoxigenina (DIG-UTP), segundo as instruções da Boheringer - Mannhein/Roche (Alemanha). A reação consistiu em $11 \mu \mathrm{L}$ do DNA preparado como descrito no item 3.2.3.2, $2 \mu \mathrm{L}$ do mix de dNTPS (nucleotídeos A, C, G e U-marcado com digoxigenina), $1 \mu \mathrm{L}$ de inibidor de RNAase, $2 \mu \mathrm{L}$ da enzima RNA polimerase T7 e $2 \mu \mathrm{L}$ do tampão da enzima (10x concentrado). A reação ocorreu em banho-maria, a $37^{\circ} \mathrm{C}$, por $2 \mathrm{~h}$. Em seguida, precipitou-se o RNA marcado com etanol (100\%). A sonda foi ressuspendida em $100 \mu \mathrm{L}$ de formamida deionizada e imediatamente armazenada em freezer $\mathrm{a}-20^{\circ} \mathrm{C}$.

\subsubsection{Hibridização "In Situ"}

\subsection{Preparo de Cortes Histológicos}

Para a hibridização in situ, calos das duas linhagens de citros em meio de multiplicação (sacarose) e em meio de obtenção de embriões (maltose) foram coletados e fixados em paraformaldeído (4\%), a $4^{\circ} \mathrm{C}$, por no máximo $24 \mathrm{~h}$. Logo depois, procedeu-se a desidratação em uma série etílica crescente até etanol $100 \%$, a $4^{\circ} \mathrm{C}$, e em seguida armazenou-se a $-20^{\circ} \mathrm{C}$ para uso posterior em hibridização in situ do tipo "whole-mount" ou para o preparo de cortes histológicos utilizados em hibridização in situ.

Para o preparo de cortes histológicos, as amostras armazenadas anteriormente foram infiltradas em solução de etanol:meio de infiltração, nas concentrações de $3: 1 ; 1: 1 ; 1: 3$, a cada $2 \mathrm{~h}$, a $4^{\circ} \mathrm{C}$, seguido de meio de infiltração 
(100\%) por 24 horas. Logo depois, as amostras foram emblocadas em resina (hidroxietilmetacrilato, Leica Heidelberg), e a polimerização foi realizada à temperatura ambiente por 1-2 dias. Em seguida, as amostras foram mantidas a $-20^{\circ} \mathrm{C}$, e seccionadas seriadamente, com espessura de $5 \mu \mathrm{m}$, em micrótomo rotativo (Leica RM2155), onde foram montadas em lâminas tratadas com 3aminopropyltriethoxysilane e água tratada com DEPC (Dietil-pirocarbonato).

As hibridizações foram realizadas segundo as técnicas descritas por Dornelas et al. (1999) e foram conduzidas em condições de baixa estringência (temperatura média de $37^{\circ} \mathrm{C}$ e 2 a $4 x$ SSC) devido ao uso de uma sonda heteróloga. $\mathrm{O}$ protocolo de hibridização seguiu basicamente o seguinte cronograma:

\section{Primeiro dia:}

Pré-hibridização: para hibridização in situ do tipo "whole-mount" as amostras preparadas como no item 3.2.3.4.1, desidratadas até etanol (100\%), foram rehidratadas em série decrescente de etanol (90\%, 70\%, 50\% e 30\% diluído em água DEPC), durante 20 minutos cada diluição, e em seguida o material foi lavado com água DEPC. Posteriormente, tanto as amostras inteiras ("wholemount") re-hidratas anteriormente, como os cortes, foram tratados com proteinase $\mathrm{K}\left(1 \mu \mathrm{g} \mathrm{mL}{ }^{-1}\right.$ em $0,05 \mathrm{M}$ Tris- $\left.\mathrm{HCl}, \mathrm{pH} 7,5\right)$ por 20 minutos a $37^{\circ} \mathrm{C}$. Este tratamento foi seguido de 2 lavagens com $0,5 \mathrm{M}$ Tris- $\mathrm{HCl}, \mathrm{pH} 7,5$, à temperatura ambiente.

Hibridização: adicionou-se o mix de hibridização (Tris-HCl 10 mM pH 7,5; 300 $\mathrm{mM} \mathrm{NaCl}$; 50\% formamida; EDTA $1 \mathrm{mM}$, Denharts 50x e dextransulfato 50\%) contendo 300-600 ng de sonda do gene AtSERK1, marcada com DIG-UTP. A hibridização foi conduzida a $37^{\circ} \mathrm{C}$, por um período de $16 \mathrm{~h}$.

\section{Segundo dia:}


Lavagem: foram realizadas quatro lavagens de 20 minutos cada, a $37^{\circ} \mathrm{C}$. As duas primeiras com SSC $4 \times\left(0,6 \mathrm{M} \mathrm{NaCl} ; 0,06 \mathrm{M} \mathrm{C}_{6} \mathrm{H}_{5} \mathrm{Na}_{3} \mathrm{O}_{7} 2 \mathrm{H}_{2} \mathrm{O}\right)$ e duas outras com SSC $2 x\left(0,3 \mathrm{M} \mathrm{NaCl} ; 0,03 \mathrm{M} \mathrm{C}_{6} \mathrm{H}_{5} \mathrm{Na}_{3} \mathrm{O}_{7} 2 \mathrm{H}_{2} \mathrm{O}\right)$. A seguir o material foi lavado 2 vezes por 10 minutos em DB1 (0,01 M Tri-HCl pH 7,5; 1 mM EDTA; $0,5 \mathrm{M} \mathrm{NaCl}$ ), à temperatura ambiente, por 10 minutos.

Bloqueamento: o material foi tratado com uma solução bloqueadora ( $2 \%$ do reagente de bloqueamento Boheringer-Mannheim/Roche em 0,05M Tris-HCl), por 4 minutos, a $37^{\circ} \mathrm{C}$.

Detecção: após nova lavagem em DB1, realizou-se a detecção da sonda com anticorpo anti-DIG, conjugado à fosfatase alcalina, diluído em solução de bloqueamento (1:2000), a $37^{\circ} \mathrm{C}$, por $2 \mathrm{~h}$.

Reação da Fosfatase Alcalina: as amostras foram lavadas em DB3 (0,1 M de Tris- $\mathrm{HCl}, 0,1 \mathrm{M} \mathrm{NaCl}$ e $0,05 \mathrm{M} \mathrm{MgCl}_{2} \cdot 6 \mathrm{H}_{2} \mathrm{O} \mathrm{pH}$ 9,5), por 5 minutos. Para a visualização do sinal utilizou-se uma solução comercial de NBT/BCIP (PIERCE, USA) como substrato da fosfatase alcalina, por $2 \mathrm{~h}$, a $37^{\circ} \mathrm{C}$. As amostras foram inspecionadas e fotografadas em microscópio invertido (Zeiss, Axiovert).

\subsection{Resultados e Discussão}

\subsubsection{Análises Anatômicas e Histoquímicas}

Os calos nucelares de laranja 'Valência' cresceram uniformemente em meio com sacarose, produzindo grande quantidade de material. De modo geral, esses calos apresentaram coloração creme, com consistência friável (Figura 1A), sendo que ocasionalmente, algumas culturas demonstraram certa oxidação. Button et al. (1974) também observaram essas 
mesmas características em calos obtidos a partir de óvulos de laranja 'Shamouti'.

Durante o período de multiplicação de calos de laranja 'Valência', também observou-se a formação de algumas estruturas de coloração esbranquiçada, semelhantes aos embriões somáticos observados em meio de multiplicação de calos (sacarose), porém não se observou continuidade no desenvolvimento dessas estruturas.

A eficiência da sacarose na multiplicação de calos de citros e a supressão da embriogênese somática já foi relatada por Kochba et al. (1982), enquanto a galactose e a lactose foram as fontes de carboidrato que mais estimularam o processo embriogênico. Button et al. (1974) observaram que a sacarose promoveu bom crescimento dos calos cítricos.

Tomaz et al. (2001) notaram a presença de alguns embriões somáticos nas linhagens de calos de laranja 'Caipira' e tangerina 'Cleópatra' em meio contendo sacarose, sugerindo elevado potencial embriogênico destas linhagens de calos.

Os estudos histológicos realizados em calos de laranja 'Valência', em meio com sacarose, apresentaram uma grande quantidade de agrupamentos celulares em constante divisão mitótica, evidenciando características de células embriogênicas (Figura 1B). Button et al. (1974) também observaram células com características semelhantes em calos de laranja 'Shamouti'. Nessas mesmas culturas de 'valência' também foram observados outros tipos de agrupamentos, em menor número, cujas células, menos túrgidas, aparentavam ter perdido a capacidade de divisão celular.

A coloração com azul de comassie mostrou que os agrupamentos embriogênicos eram compostos por células com núcleo proeminente, corados em azul, e vacúolo relativamente grande, pressionando citoplasma e núcleo á membrana plasmática (Figura $1 \mathrm{C}$ ). Em relação ao acúmulo de amido nas culturas, observou-se maior concentração nos agrupamentos que apresentavam menor taxa de divisão celular (Figura 1D), sugerindo uma maior 
utilização das reservas de amido durante as divisões celulares provavelmente para formação dos agrupamentos embriogênicos.

Calos de laranja 'Valência' em meio para obtenção de embriões com maltose apresentaram regiões nos agrupamentos celulares com maior intensidade de divisão celular (Figura 1E), indicando o início de desenvolvimento de embriões somáticos. Essas células possuíam núcleos grandes e citoplasma mais denso em relação às células em meio com sacarose, com maior acúmulo de proteínas em relação às células em baixa atividade mitótica (Figura 1F). Já os agrupamentos que não estavam se dividindo apresentavam elevada concentração de amido, comparativamente às células em intensa atividade de divisão mitótica (Figura 1G).

Cabasson et al. (1995) descreveram dois tipos de células nos agrupamentos celulares de Citrus deliciosa. O tipo mais abundante tinha citoplasma vacuolado com grande acúmulo de grãos de amido, enquanto as células de ocorrência menos freqüente, consideradas embriogênicas, possuíam pequenos grãos de amido e uma alta relação núcleo plasmática, semelhantes aos observados no presente estudo.

Gavish et al. (1991) analisaram morfologicamente culturas de células de citros em suspensão contendo sacarose. Essas células também mostraram grandes agrupamentos formados por células altamente vacuoladas. Dois dias após a transferência das culturas para meio contendo glicerol, observaram-se células menores, com citoplasma denso, que se desenvolveram para formar embriões globulares depois de três semanas.

De acordo com Sharp (1980) e Williams \& Maheswaran (1986), as células embriogênicas, de modo geral, apresentam características comuns ao comportamento de células embrionárias ativas, incluindo rápida divisão mitótica, pequeno tamanho, citoplasma denso, núcleo grande com nucléolo proeminente, vacúolos pequenos e abundância de grãos de amido. Essas características sugerem uma intensa síntese de RNA e ampla atividade metabólica. 
Figura 1 - Agregados celulares de cultura de calos de laranja 'Valência'. Culturas em meio de multiplicação com sacarose (A-D) e em meio para obtenção de embriões com maltose $(E-H)$, evidenciando características das culturas em multiplicação (A) e após a formação de embriões $(H)$; características estruturais das culturas em sacarose (B) e em maltose (E) através de coloração de com azul de toluidina e fucsina ácida; coloração com azul de comassie para visualização de proteínas (C e F), e coloração com cloreto de zinco para visualização de amido (D e G). Barras: $A=1 \mathrm{~mm}$; $B-G=100 \mu \mathrm{m}$; $\mathrm{H}=500 \mu \mathrm{m}$ 


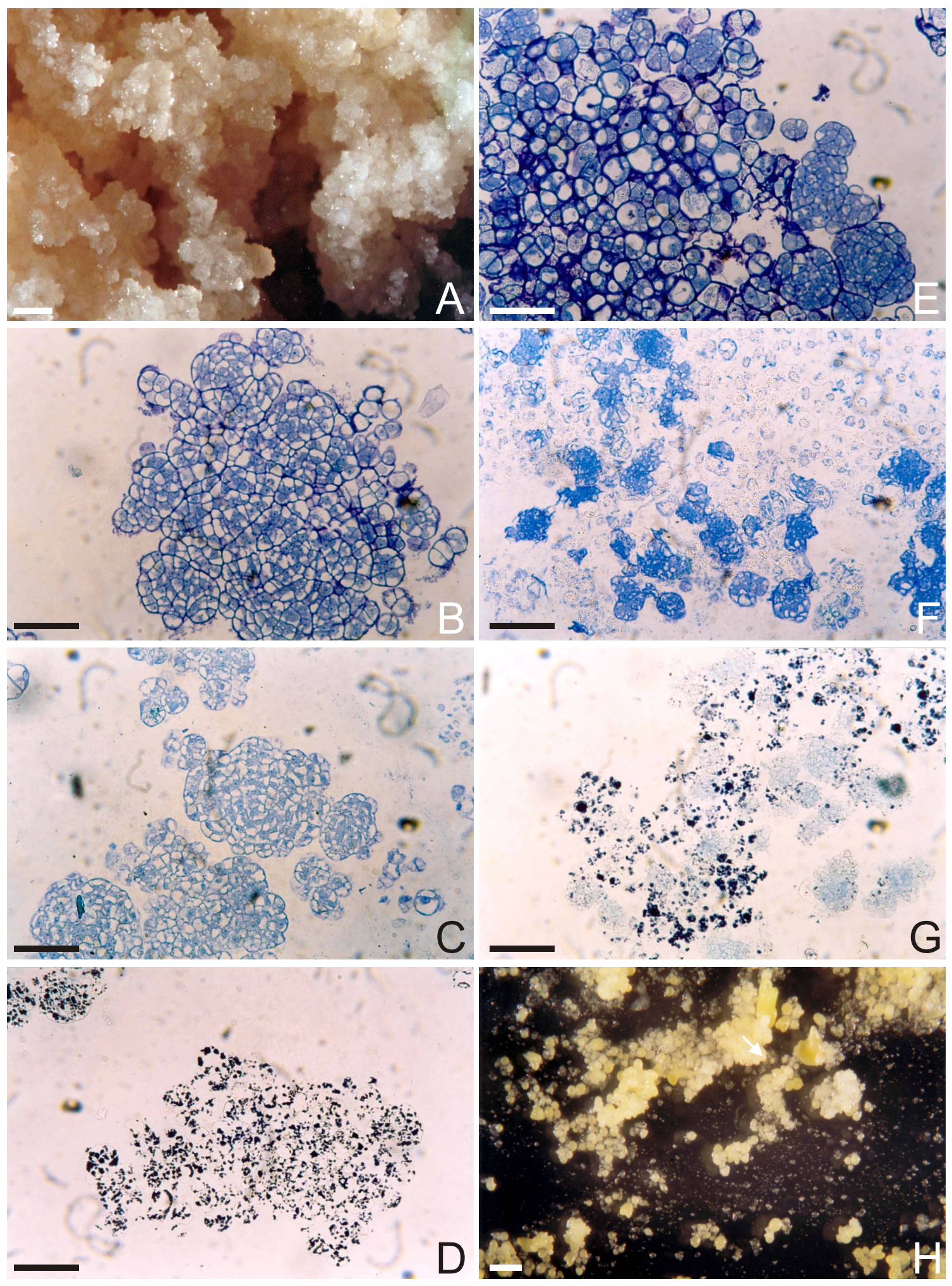


No presente estudo, a formação de embriões somáticos foi observada inicialmente, cerca de 20 dias após a transferência dos calos do meio com sacarose para o meio com maltose (Figura $1 \mathrm{H}$ ). Após cerca de 30 dias, foi possível observar um número elevado de embriões somáticos em diferentes fases de desenvolvimento, em uma mesma placa. O mesmo comportamento foi observado por Perez et al. (1998) e Tomaz et al. (2001), os quais também observaram assincronia em culturas de calos de laranjas doces. Komatsuda et al. (1992) observaram em cultura de soja a presença de pequenos embriões somáticos, de coloração verde e morfologicamente normais.

Apesar da falta de sincronia nas culturas de 'Valência', os embriões formados seguiram, de maneira geral, os estágios embriogênicos globular, coração e cotiledonar, semelhante à embriogênese zigótica (Figura 2A-D). A maioria dos embriões somáticos formados apresentaram-se morfologicamente normais, porém, alguns embriões apresentaram cotilédones múltiplos, ou ainda um só cotilédone, tendo-se observado também a ocorrência de fusão de embriões (Figura 3A-F).

Segundo Zimmerman (1993), a seqüência de desenvolvimento da embriogênese somática similar à embriogênese zigótica é considerada como padrão para o cultivo in vitro. Entretanto, apesar de embriões somáticos se assemelharem aos embriões zigóticos em todas as fases, também é notório que muitas formas anormais podem ser encontradas, como relatado por Gmitter Junior \& Moore (1986); Rodriguez \& Wetzstein (1994, 1998); Ricci et al. (2002). Gmitter Junior \& Moore (1986) relataram a ocorrência de anormalidades no desenvolvimento de embriões somáticos em culturas de óvulos não desenvolvidos de espécies poliembriônicas de citros, tais como múltiplos cotilédones, múltiplos meristemas caulinares, e embriões fusionados. 

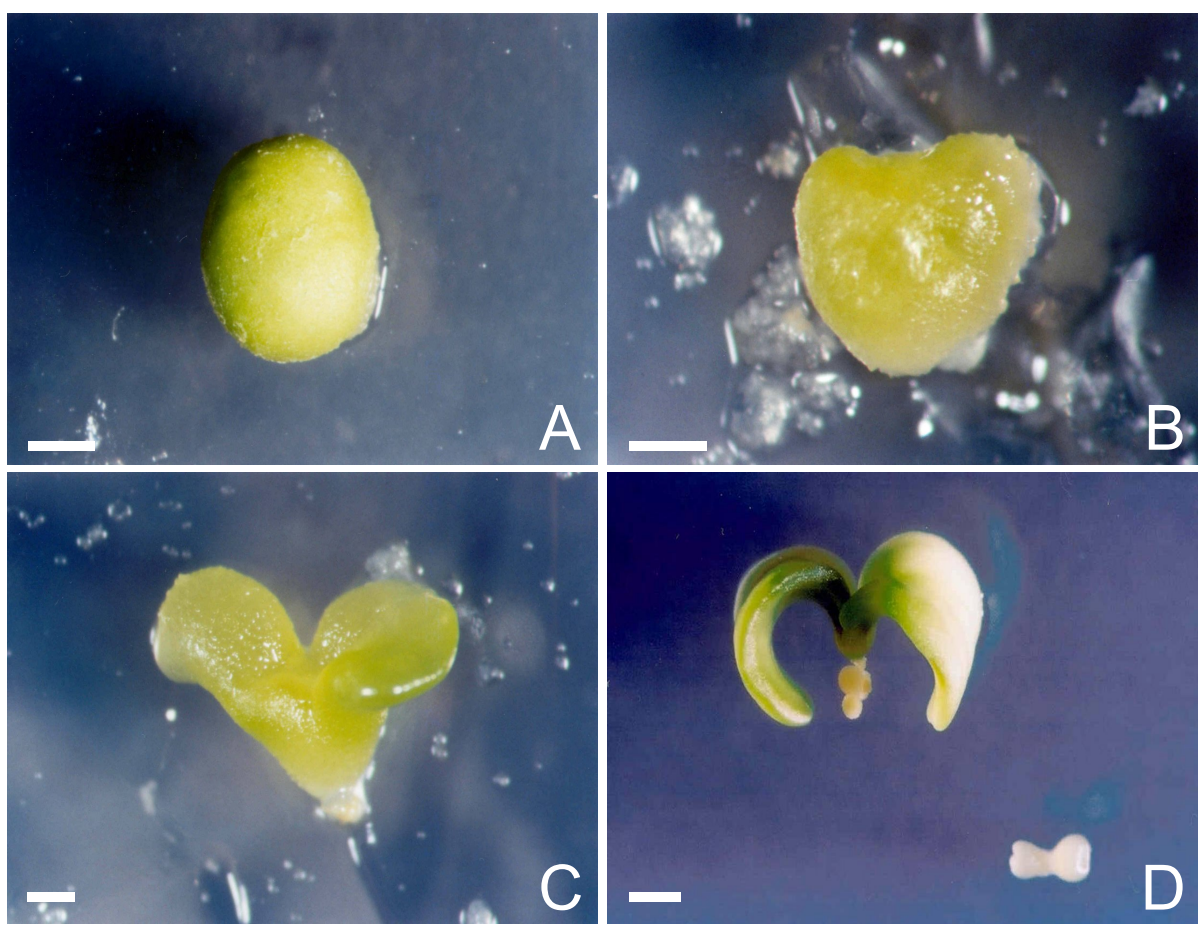

Figura 2 - Embriões somáticos em culturas de laranja 'Valência'. Embriões em estádio globular (A), cordiforme (B), cotiledonar ( $C$ e D). Barras: $A=1 \mathrm{~mm} ; B=500 \mu \mathrm{m} ; C=100 \mu \mathrm{m}$; $\mathrm{D}=500 \mu \mathrm{m}$ 

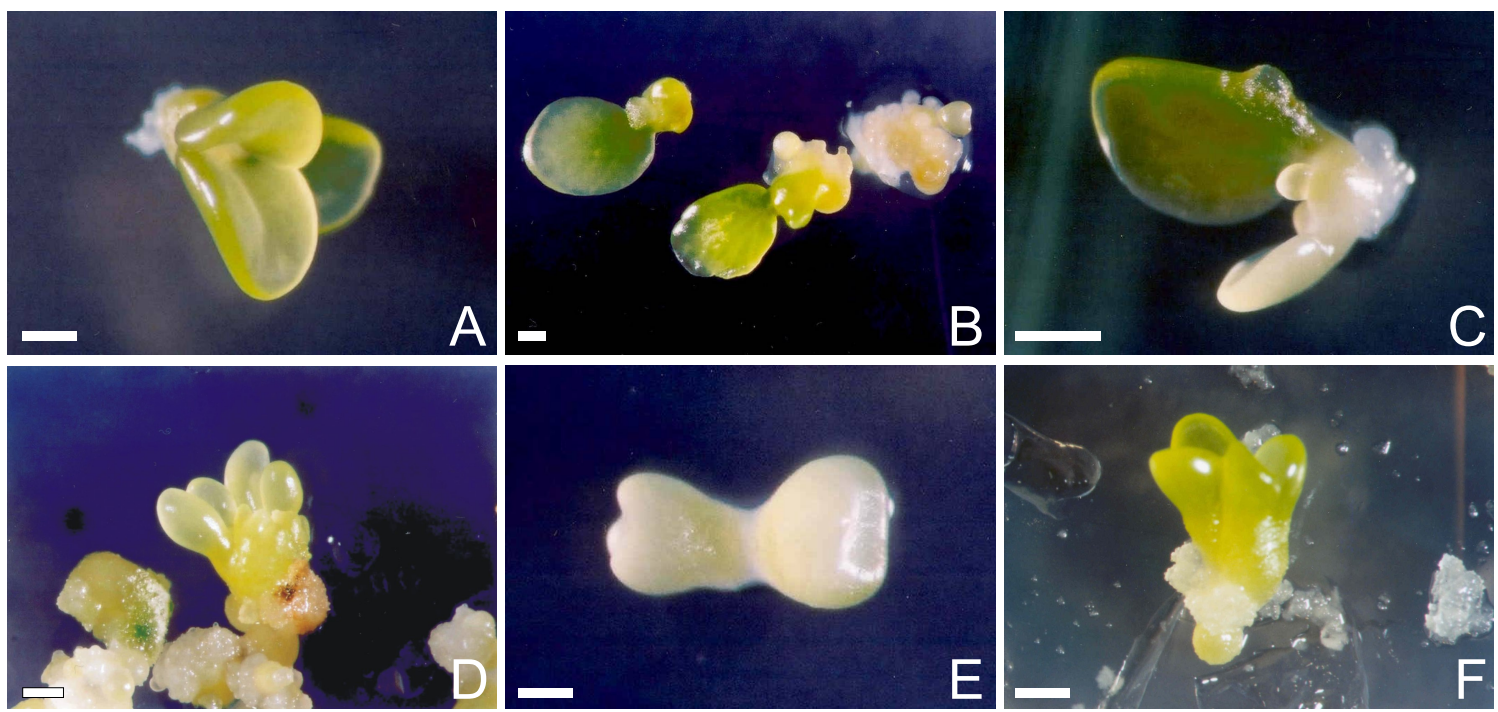

Figura 3 - Embriões somáticos com alterações estruturais, em culturas de laranja 'Valência'. Embrião com três cotilédones $(A)$, com apenas um cótilédone $(B)$, cotilédones de tamanhos diferentes (C), embriões fusionados (D-F). Barras: $\mathrm{A}-\mathrm{E}=500 \mu \mathrm{m} ; \mathrm{F}=100 \mu \mathrm{m}$ 
Igualmente, Rodriguez \& Wetzstein $(1994,1998)$ também relatam anormalidades no desenvolvimento de embriões somáticos de pecan (Carya illinoinensis). Dornelas et al. (1992) observaram a formação de alguns embriões somáticos de Stylosanthes scabra com desenvolvimento anormal. Ammirato (1987) relata que além de embriões únicos, podem ser encontrados embriões gêmeos, trigêmeos e agrupamentos múltiplos. Estas anormalidades podem, por sua vez, gerar múltiplos ápices vegetativos após a germinação.

Mendes-da-Glória et al. (2001) notaram alterações morfológicas como cotilédones sem angulações, ausência de diferenciação do ápice caulinar e/ou radicular, eixo embrionário colapsado e embriões anisocotiledonares, mesmo em embriões nucelares in vivo de laranja 'Valência'. Dentre as másformações observadas as que podem estar relacionadas à baixa conversão em plantas são o eixo embrionário colapsado e a ausência de desenvolvimento do meristema apical caulinar.

A análise histológica de embriões em diferentes fases de desenvolvimento permitiu a observação da diferenciação de tecidos durante o desenvolvimento dos embriões somáticos de laranja 'Valência', com a formação de protoderme, faixas procambiais e definição dos meristemas caulinar e radicular (Figura 4A-C).

Cabasson et al. (1995) observaram, através de análises histológicas, que embriões somáticos de Citrus deliciosa em meio de cultura suplementado com galactose desenvolviam um pólo radicular, uma zona procambial, mas com uma notável ausência de epiderme. Tomaz et al. (2001) constataram histodiferenciação adequada em embriões somáticos de laranjas 'Valência', 'Seleta Vermelha' e 'Caipira'.

Nas culturas de limão 'Cravo', observou-se que os calos em meio de multiplicação, com sacarose, se multiplicaram uniformemente, porém mais lentamente, em relação às culturas de 'Valência'. As culturas de calos apresentaram-se com coloração creme e aspecto úmido, sendo que a oxidação foi mais intensa do que em 'Valência' (Figura 5A). 


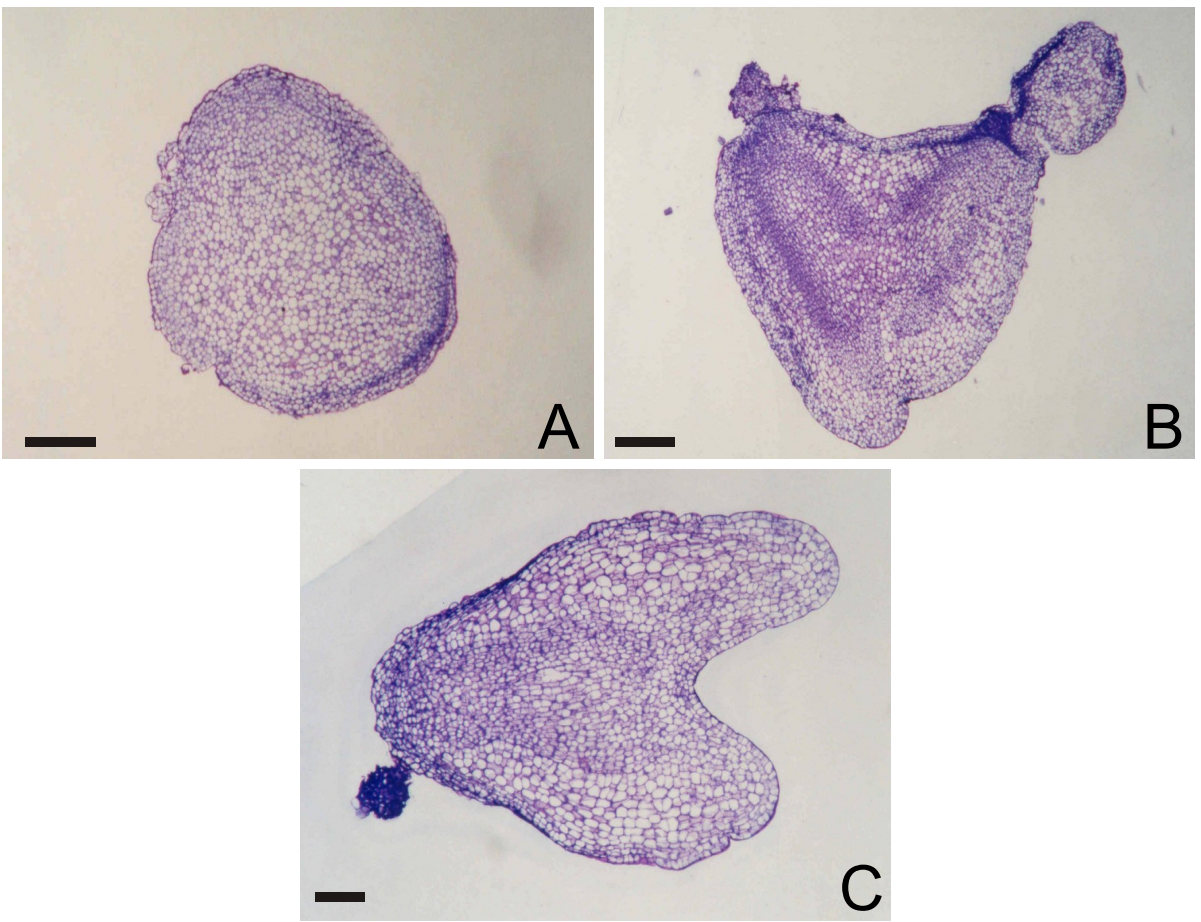

Figura 4 - Cortes histológicos de embriões somáticos de laranja 'Valência'. Embrião em estádio globular (A), cordiforme (B) e cotiledonar (C). Barras: $A-B=200 \mu \mathrm{m} ; C=100 \mu \mathrm{m}$ 
Anatomicamente, os calos de limão 'Cravo' em meio de multiplicação (Figura 5E) mostraram agrupamentos de células menos denso, com células grandes, vacúolo volumoso e o citoplasma pressionado contra a membrana celular. Alguns pequenos agrupamentos de células foram também observados, sendo geralmente compostos por 3 a 4 células pequenas (Figuras 5B). Estes, em sua maioria apresentaram-se com núcleo grande, citoplasma denso, e com intensa coloração de azul de comassie, indicando grande acúmulo de proteínas (Figura $5 \mathrm{C}$ ), e pequeno acúmulo de amido evidenciado pela coloração com lugol. Já as células maiores, aparentemente não embriogênicas, apresentaram pequena concentração de proteínas e elevado acúmulo de amido (Figura 5D), assim como observado em 'Valência'. Em meio para obtenção de embriões, com maltose (Figura $5 \mathrm{E}$ ), as culturas de calos de limão 'Cravo', apresentaram estruturas globulares, possivelmente embriões em estádio globular, porém, diferentemente do observado em 'Valência', as células apresentaram pequeno acúmulo de proteínas, indicando baixa atividade metabólica. Acúmulo de amido foi observado em algumas células, ou grupos celulares, semelhante ao observado em 'Valência'.

De acordo com Bewley \& Black (1994) os carboidratos são as principais fontes de carbono e energia das células, sendo as maiores reservas de quase todas as sementes, comumente armazenados sob a forma do polissacarídeo amido. O amido é proveniente principalmente da sacarose, um dissacarídeo composto de uma molécula de glicose e frutose, que é convertida em glicose no citoplasma, e entra nos amiloplastos para ser convertido em amido. 
Figura 5 - Agregados celulares de cultura de calos de limão 'Cravo'. Culturas em meio de multiplicação com sacarose (A-D) e em meio para obtenção de embriões com maltose $(E-H)$, evidenciando características das culturas em multiplicação (A) e em meio de obtenção de embriões (E); características estruturais das culturas em sacarose (B) e em maltose (F) através de coloração de com azul de toluidina e fucsina ácida; coloração com azul de comassie para visualização de proteínas ( $C$ e G), e coloração com cloreto de zinco para visualização de amido $(D$ e $H)$. Barras: $A=1 \mathrm{~mm}$; $B-$ $\mathrm{D}=100 \mu \mathrm{m} ; \mathrm{E}=500 \mu \mathrm{m} ; \mathrm{F}-\mathrm{H}=100 \mu \mathrm{m}$ 

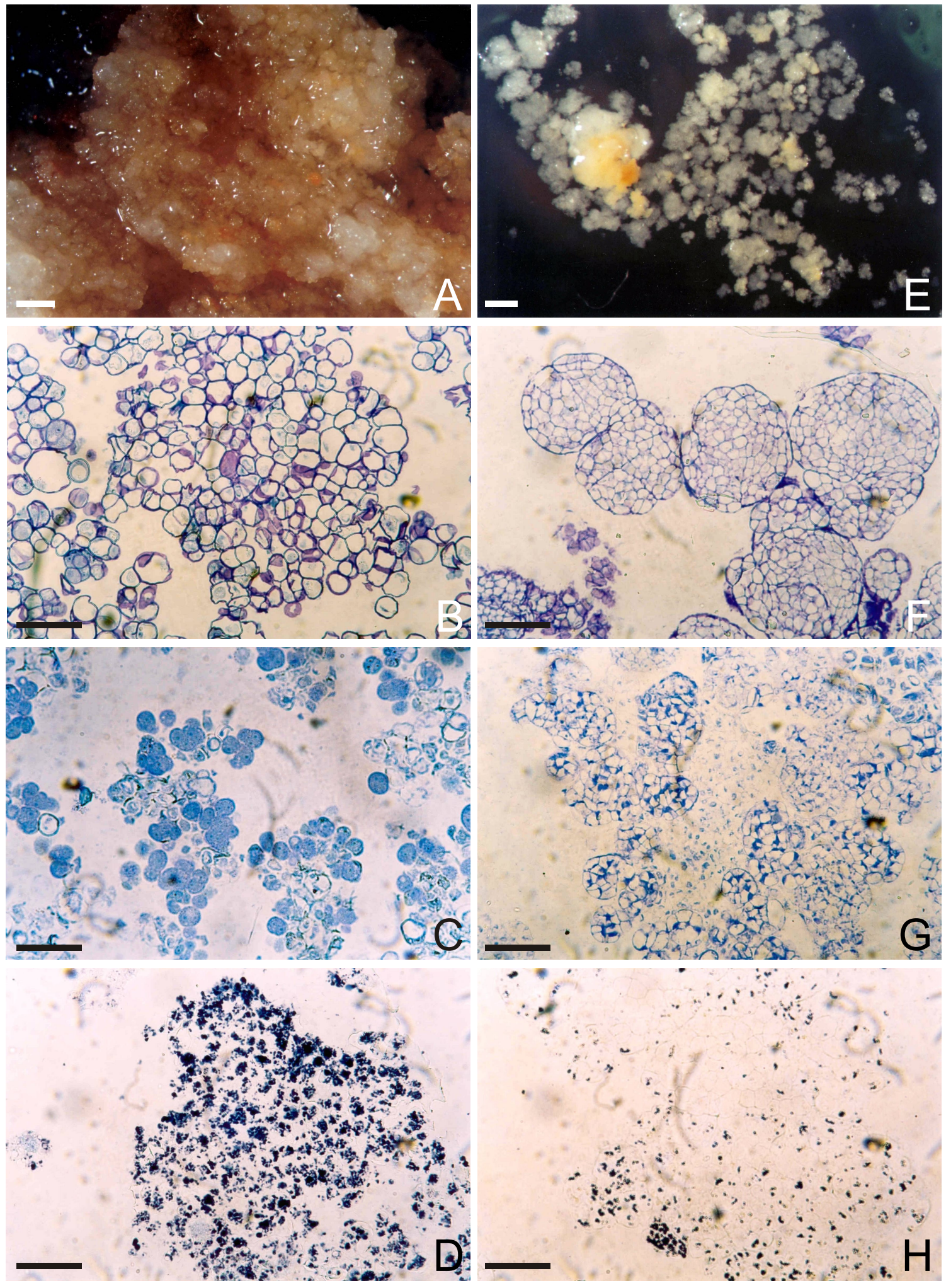

- of 20320

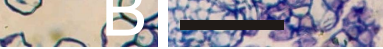
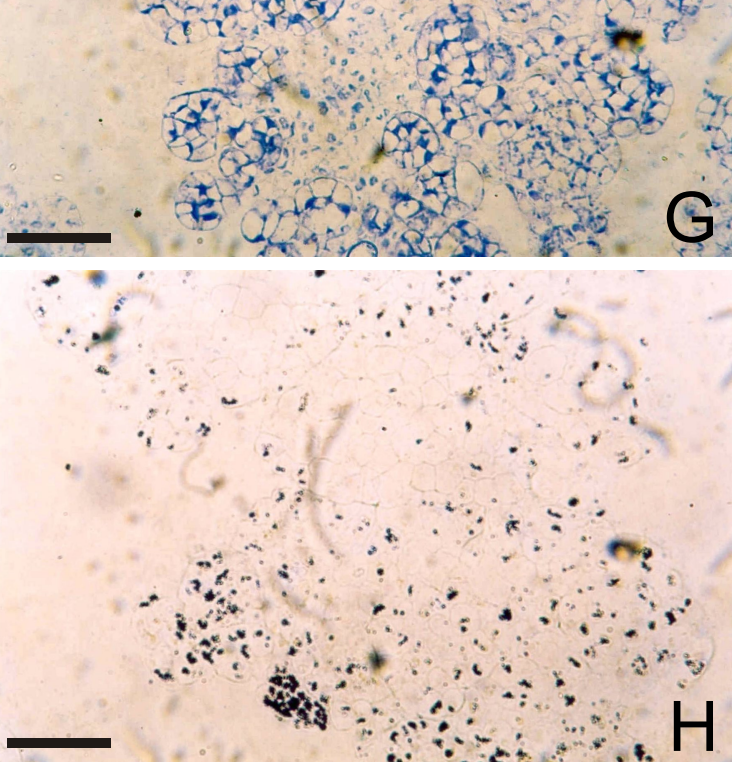
A formação de embriões somáticos em limão 'Cravo' ocorreu somente após 35 dias de transferência dos calos do meio de multiplicação para o meio com maltose (Figura 6A). Houve uma baixa resposta do limão 'Cravo' ao estímulo ao desenvolvimento de embriões, verificando-se que os poucos embriões somáticos formados apresentavam-se deformados. A continuidade no desenvolvimento desses embriões não foi observada, confirmando a característica de uma linhagem com baixo potencial embriogênico. Em alguns casos, observou-se a formação de estruturas com a aparência de um aglomerado de cotilédones (Figura 6B). Anormalidades similares foram observadas em culturas de citros por Ricci et al. (2002). Tomaz et al. (2001) relataram anormalidades no estímulo e desenvolvimento dos embriões somáticos para linhagens de calo de limão 'Cravo' e tangerina 'Cleópatra'. Moore (1985) também observou anormalidades em embriões somáticos de limão 'Bears'.

As características dos calos de limão 'Cravo', com baixa atividade mitótica, tanto em sacarose como em maltose, bem como o pequeno acúmulo de proteínas em meio com maltose, sugerem dificuldades no desenvolvimento embrionário. Análises histológicas de estruturas semelhantes a embriões, formadas em culturas de limão 'Cravo', mostraram ausência de histodiferenciação (Figuras 6C-D). Não foram observados embriões nos estádios subseqüentes de desenvolvimento.

De acordo com Rodriguez \& Wetzstein (1994) a morfologia do embrião somáticopode afetar o desenvolvimento subseqüente em plantas. Em alguns casos, os embriões anormais ou mal-formados possuem freqüências mais baixas de conversão em plantas do que aqueles que se assemelham aos embriões zigóticos. Gmitter Junior \& Moore (1986) observaram que o desenvolvimento de muitos dos embriões foram paralisados como resultado das anormalidades ocorridas em embriões somáticos de citros. 

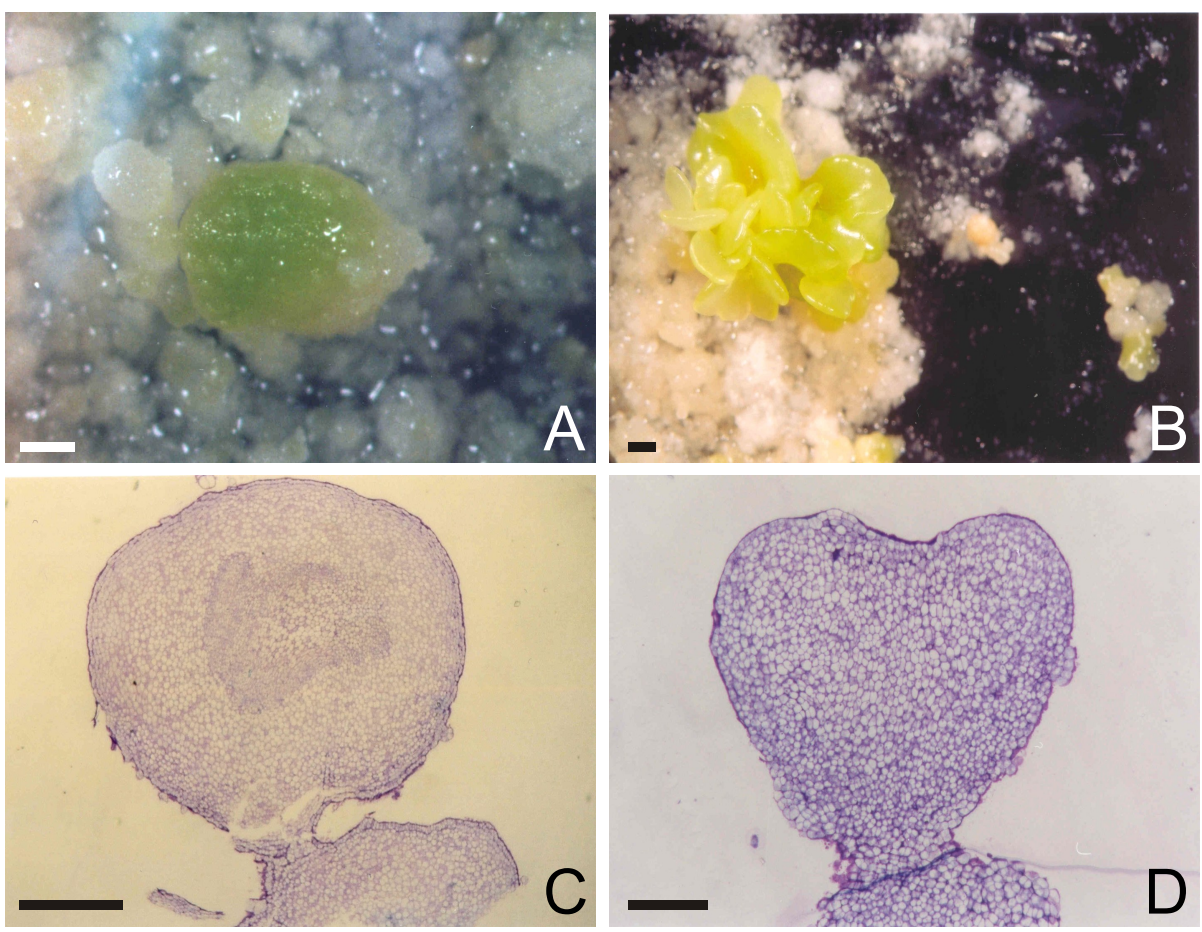

Figura 6 - Embriões somáticos de limão 'Cravo'. Embrião em estádio globular (A) e pluricotiledonar (B). Cortes histológicos de embriões somáticos em estádio globular (C) e cordiforme (D). Barras: $A-B=1000 \mu \mathrm{m} ; C=500 \mu \mathrm{m} ; \mathrm{D}=200 \mu \mathrm{m}$ 
Os resultados acima descritos evidenciaram que existem diferenças anatômicas entre os calos das duas linhagens de citros, que foram observadas através das análises histológicas e histoquímicas, ainda que a olho nu os calos de limão 'Cravo' se assemelhem aos calos de laranja 'Valência'. Segundo Tomaz et al. (2001) de maneira geral os calos mostram diferenças nas respostas, confirmando que o genótipo influencia no crescimento dos calos e no desenvolvimento dos embriões somáticos.

A formação de embriões somáticos, bem como a histodiferenciação em meio com maltose, não ocorreram do mesmo modo para as duas espécies de citros, confirmando as observações de Tomaz et al. (2001), que relataram que o desenvolvimento de embriões somáticos de citros pode variar conforme o genótipo. Perez et al. (1998) também observaram que a formação de embriões somáticos em cultura de calos de citros é dependente da espécie.

O desenvolvimento de embriões somáticos em laranja 'Valência' mostrou ser muito superior quantitativa e qualitativamente, em comparação ao material de limão 'Cravo', confirmando a denominação dos sistemas descritos por Tomaz et al. (2001) de "altamente embriogênico" e "pouco embriogênico", respectivamente.

Nas culturas dos calos, de ambas as linhagens de Citrus, foi observado um decréscimo na produção e desenvolvimento de embriões somáticos. É comumente observado que calos e culturas em suspensão inicialmente capazes de desenvolver organogênese ou embriogênese, mostram perda progressiva dessa habilidade morfogenética quando mantidos por vários subcultivos, mesmo em meio capaz de manter seu contínuo crescimento in vitro (Smith \& Street, 1974). Segundo Grattapaglia \& Machado (1998) embora a capacidade de regeneração de plantas seja inicialmente muito alta, as células podem perder gradativamente esse potencial após alguns subcultivos. Esta perda da capacidade embriogênica das células é uma das limitações do processo embriogênico para a multiplicação contínua de algumas espécies. $O$ 
potencial embriogênico da cultura é maior quando esta é relativamente mais nova, ou seja, no primeiro ano de subcultivo (Zimmerman, 1993).

\subsubsection{Expressão do Gene SERK1}

A expressão heteróloga do gene SERK1 de Arabidopsis (AtSERK1) em culturas de calos nucelares de C. sinenis, var. 'Valência', e C. limonia, var. limão 'Cravo', foi analisada utilizando-se a técnica de hibridização in situ, tanto em cortes histológicos, como em materiais inteiros ("wholemount"). A presença dos transcritos dos homólogos de AtSERK1 de laranja 'Valência' e limão 'Cravo', pôde ser detectada pela coloração violácea característica, gerada pela reação da fosfatase alcalina, conjugada ao anticorpo anti-DIG com o seu substrato.

Antes mesmo da avaliação da hibridização ('whole-mount') com a sonda do gene AtSERK1 nos calos, a solução contida nos eppendorfs já demonstrava sinal de hibridização, indicando que a reação de hibridização havia ocorrido. Logo, era possível identificar diferenças de expressão do gene AtSERK1 entre as linhagens de citros e também em relação aos tratamentos, através da intensidade do sinal de hibridização na solução (Figura 7). Observou-se que o sinal foi mais intenso em calos de laranja 'Valência' do que em limão 'Cravo', sendo que a expressão foi maior nos calos em meio de multiplicação, com sacarose, do que nos calos em meio de obtenção de embriões, com maltose, para ambas as espécies.

Em milho, os genes ZmSERK1 e ZmSERK2, que possuem características da família dos genes SERK, foram expressos em calos embriogênicos e não embriogênicos, contrastando com DCSERK e AtSERK, que se expressaram somente em estruturas embriogênicas (Baudino et al., 2001). 


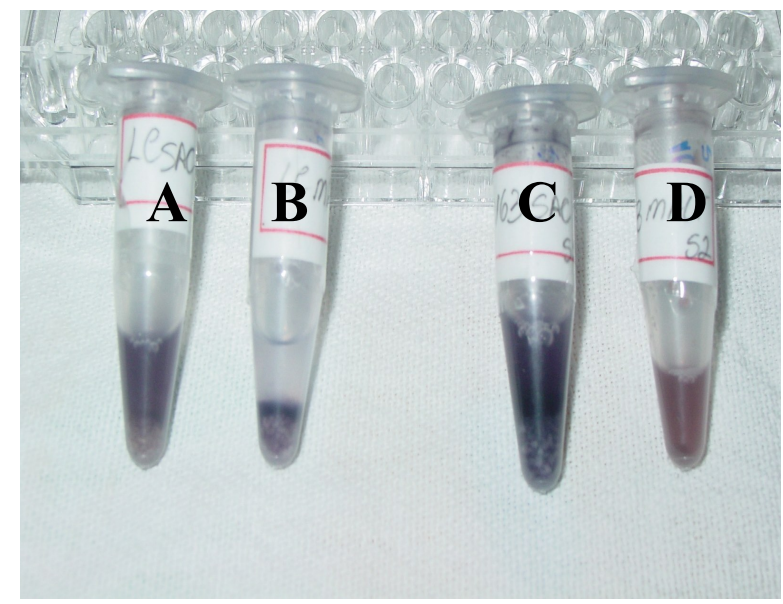

Figura 7 - Diferenças de intensidade na expressão do gene AtSERK1, observadas na solução de hibridização com amostras do tipo "whole-mount" de cultura de calos de citros. Amostras de calos de limão 'Cravo' em meio de multiplicação (sacarose) (A), e meio para obtenção de embriões (maltose) (B); e laranja 'Valência' em meio com sacarose (C) e maltose (D) 
Os transcritos de AtSERK1 foram detectados nas hibridizações do tipo "whole-mount" de cultura de calos das duas linhagens de citros em meio de multiplicação, com sacarose (Figura 8A e C), e em meio de obtenção de embriões, com maltose (Figura 8B e D). Estes resultados indicam que as culturas de laranja 'Valência' e limão 'Cravo' possuem células competentes e com potencial embriogênico, mesmo antes da transferência para o meio de obtenção de embriões. O sinal de AtSERK1 em células de culturas competentes foi relatado anteriormente em outras espécies (Schmidt et al., 1997; Baudino et al., 2001; Hecht et al., 2001).

As hibridizações realizadas em cortes histológicos, utilizando-se como resina o Kit Historesin, apresentaram resultados positivos, porém há maior dificuldade nesse tipo de metodologia. Na Figura 9 pode-se observar a expressão do gene AtSERK1 em laranja 'Valência', comprovando-se a eficiência da técnica. As dificuldades da metodologia estão relacionadas à perda dos cortes histológicos durante o processo, por serem realizadas inúmeras lavagens no material. Há necessidade de melhor ajuste nesta metodologia, já que os resultados não puderam ser comprovados em amostras de limão 'Cravo' por perda de material.

Nossos resultados também sugerem que a baixa freqüência de formação de embriões somáticos em culturas de calos de limão 'Cravo' provavelmente é influenciada por outros fatores além do gene SERK. Segundo Hecht et al. (2001) o AtSERK1 não é somente um marcador de células competentes para formar embriões, mas também está envolvido em conferir competência embriogênica. Porém, outros genes também estão envolvidos no processo de embriogênese, e várias vias diferentes e independentes influenciam a competência embriogênica. 

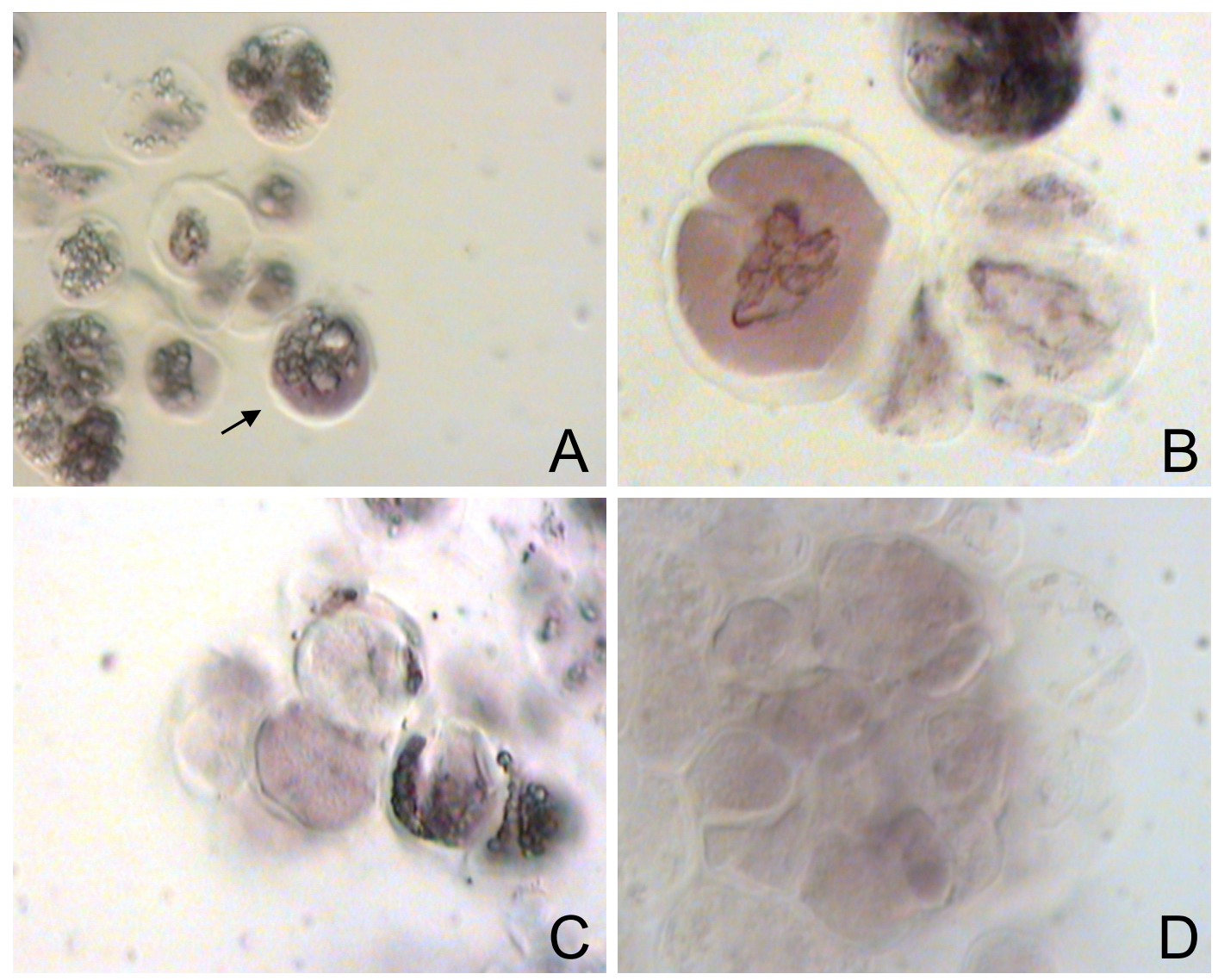

Figura 8 - Análise da expressão do gene AtSERK1 através de hibridização in situ do tipo "whole-mount" em calos de citros. Calos de laranja 'Valência' em meio com sacarose (A) e maltose (B); calos de limão 'Cravo' em meio com sacarose (C), e maltose (D), hibridizados com sonda do gene AtSERK1, mostrando regiões ou células com a expressão do gene, indicada pela coloração violácea (seta em A) e células que não apresentam a coloração violácea, indicando a ausência de expressão do gene 

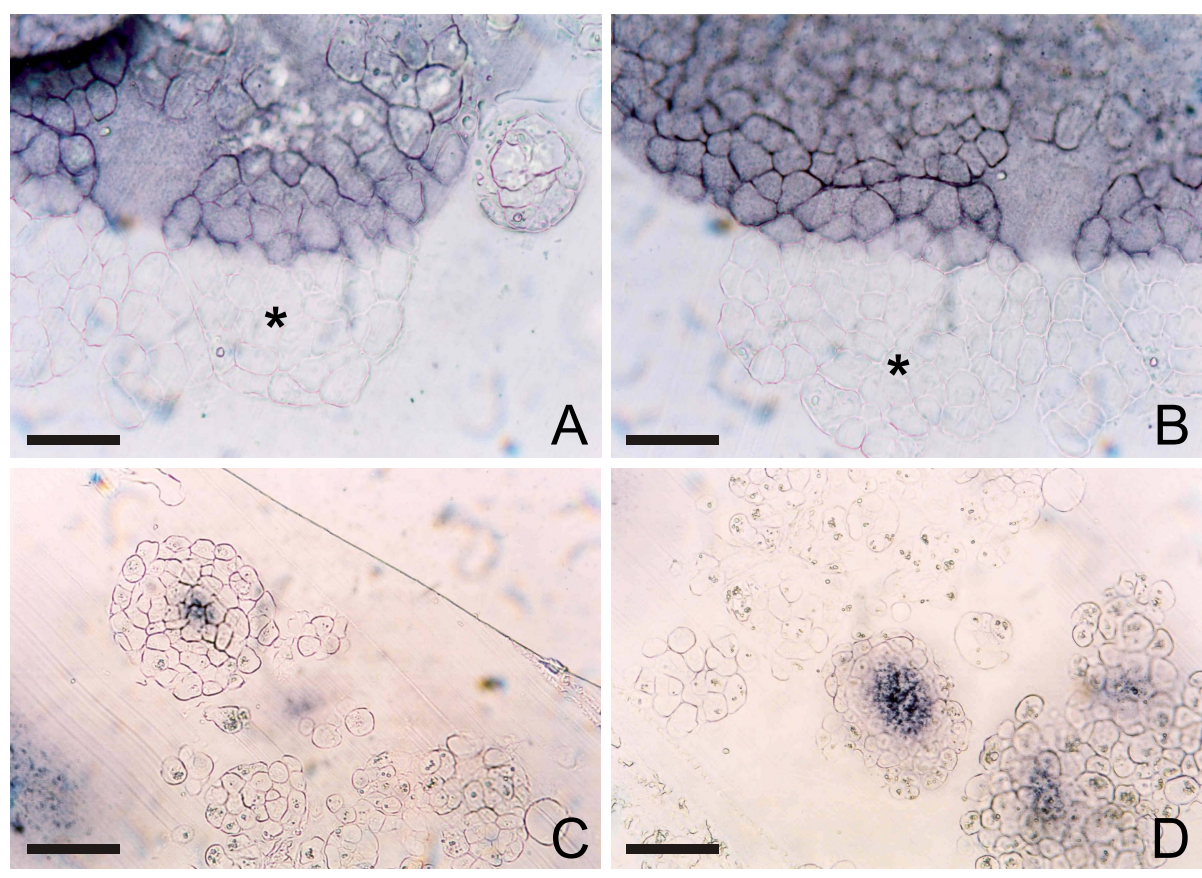

Figura 9 - Expressão do gene AtSERK1 através de hibridização in situ em cortes histológicos de calos de citros. Calos hibridizados de laranja 'Valência' em meio para multiplicação de calos, com sacarose (A-B) e calos hibridizados de laranja 'Valência' em meio para obtenção de embriões, com maltose (C-D), mostrando as células que estão expressando o gene com coloração violácea. Barras $=100 \mu \mathrm{m}$ 
A expressão de um gene relacionado ao processo embriogênico de $A$. thaliana, AtSERK1, em citros, comprova que este gene é conservado evolutivamente, sendo expresso no processo de embriogênese zigótica em arabidopsis e somática em citros. De acordo com Schmidt et al. (1997) este gene é altamente conservado em mono e dicotiledôneas.

Estudos moleculares são importantes ferramentas que estão sendo utilizadas para auxiliar no entendimento do processo de desenvolvimento de plantas. A formação de embriões de plantas necessita da ativação de um grupo específico de genes (Goldberg et al.,1994). Diversos genes foram relatados como prováveis marcadores de agrupamentos celulares embriogênicos (Zimmerman, 1993).

\subsection{Conclusões}

Os resultados obtidos permitem afirmar que nas duas condições observadas, meio de multiplicação, com sacarose, e meio de obtenção de embriões, com maltose, existem diferenças anatômicas e histoquímicas entre as duas espécies de citros, sendo que calos de laranja 'Valência' apresentaram em sua maioria, agrupamentos de células com características embriogênicas. Células aparentemente embriogênicas, em rápida divisão celular, de tamanho pequeno, apresentavam maior concentração de proteínas e menor concentração de amido, quando comparadas às células maiores, mais vacuoladas, aparentemente menos embriogênicas.

O sinal de expressão do gene AtSERK1 foi observado nos calos de ambas as espécies de citros, mesmo antes de transferência para meio de obtenção de embriões, evidenciando que as culturas de ambas as espécies, apesar de diferenças de eficiência embriogênica, possuem células competentes para a expressão da embriogênese somática. A metodologia utilizada permitiu comprovar a conservação evolutiva deste gene, tanto em espécies diferentes, como em relação a processos embriogênicos, zigótico e somático. 


\section{INFLUÊNCIA DA SEPARAÇÃO DE AGRUPAMENTOS CELULARES E DE TRATAMENTOS DE ESTRESSE NA OBTENÇÃO DE EMBRIÕES SOMÁTICOS A PARTIR DE CULTURA DE CALOS EM Citrus sinensis L. OSBECK, var. VALÊNCIA}

Resumo

A embriogênese somática já foi relatada em várias espécies de citros com diferentes resultados em termos de sincronia e conversão em plantas. Tanto a qualidade, quanto a quantidade de embriões somáticos produzidos depende de fatores genéticos e fisiológicos, os quais são influenciados pelas condições ambientais em que a cultura de calos é mantida. Diversos autores demonstram que períodos de estresse durante o cultivo in vitro podem promover aumentos nas taxas de indução, maturação e/ou germinação de embriões somáticos. Neste trabalho avaliamos o efeito de alguns tratamentos como: dessecação, frio e tamanhos dos agrupamentos celulares, na sincronização e eficiência de obtenção de embriões somáticos a partir de cultura de calos de Citrus sinensis L. Osbeck, variedade Valência. Calos nucelares cultivados em meio de multiplicação EME sólido, suplementado com $50 \mathrm{~g} \mathrm{~L}^{-1}$ de sacarose, foram coletados e mantidos no mesmo meio, porém líquido, em agitador orbital a $200 \mathrm{rpm}$ durante $24 \mathrm{~h}$ e posteriormente peneirados de acordo com o tratamento. Utilizaram-se peneiras com malhas de $150 \mu \mathrm{m}$ (P1), $300 \mu \mathrm{m}$ (P2) e $600 \mu \mathrm{m}$ (P3), para separação das culturas conforme o tamanho dos agregados. Além do efeito de tamanho de agregados, também foi observado o efeito da exposição ao frio colocando-se os calos a $4^{\circ} \mathrm{C}$, por quatro 
semanas, em ausência de luz, e o efeito da exposição à dessecação, mantendo-se os calos a $27^{\circ} \mathrm{C}$, em placas de Petri, em ausência de meio de cultura e de luz, por 6 dias, seguido de cultivo a $26 \pm 1^{\circ} \mathrm{C}$ e intensidade luminosa de 300 lux. Os resultados permitiram concluir que todos os tratamentos foram melhores do que a testemunha, em relação à produção e desenvolvimento de embriões somáticos, sendo que a separação em tamanho de agregados celulares apresentou resultados ainda melhores do que os tratamentos de estresse. A combinação entre separação de agregados celulares e tratamentos de estresse apresentou os melhores resultados. O desenvolvimento de embriões somáticos em Citrus sinensis var. Valência, ocorre mais eficientemente a partir de agregados celulares de tamanhos específicos, não podendo-se, porém afirmar se há, ou não, possibilidade de que haja formação de embriões somáticos a partir de células únicas, através dos experimentos conduzidos neste trabalho. Análises histológicas e histoquímicas foram realizadas para caracterização dos agregados celulares, em termos estruturais e de acúmulo de proteínas e amido.

\section{Summary}

Somatic embryogenesis has been obtained in several citrus species with various responses in terms of synchrony of cultures and conversion of embryos in plants. Both quality and quantity of somatic embryos produced depend on genetic and physiological factors, which are influenced by the culture conditions in which the calli are maintained. Many authors have demonstrated that stress may increase the rate of induction, maturation and/or germination of somatic embryos. In the present work we evaluate the effect of desiccation, cold and size of cell clusters in synchronization and embryo production efficiency in callus cultures of Citrus sinensis L. Osbeck, var. Valencia. Nucellar callus cultivated in EME solid medium supplemented with $50 \mathrm{~g} \mathrm{~L}^{-1}$ was collected and maintained in the same medium, but liquid, under agitation at $200 \mathrm{rpm}$, during 
$24 \mathrm{~h}$, and then sieved and cultured according to the following treatments. Sieves of $150 \mu \mathrm{m}$ (P1), $300 \mu \mathrm{m}$ (P2) and $600 \mu \mathrm{m}$ (P3) were used to separate the cultures in different cluster sizes. Besides the effect of cluster size, treatments of cold $\left(4^{\circ} \mathrm{C}\right.$ for four weeks in the dark) and desiccation $\left(27^{\circ} \mathrm{C}\right.$, in Petri dishes in absence of medium and in the dark, during 6 days) were also tested, followed by cultivation at $26 \pm 1^{\circ} \mathrm{C}$ and light intensity of 300 lux. The results showed that all the treatments were more efficient than the control in terms of embryo production and development, with cell aggregate separation showing more expressive results than stress treatments. The combination of separation of cell aggregates and stress gave the best results. The development of somatic embryos in callus cultures of 'Valencia' sweet orange occurs more efficiently from cell aggregates of specific sizes, however it was not possible to confirm if somatic embryos are originated from single cells with the experiments done in this research. Histological and histochemical analysis are presented to characterize the cell aggregates in terms of structure and protein and starch accumulation.

\subsection{Introdução}

Atualmente, encontram-se descritas na literatura várias técnicas de cultura de tecidos em citros, entre elas a embriogênese somática que se constitui numa via de regeneração de plantas in vitro na qual células, ou agrupamentos de células somáticas, desenvolvem-se formando estruturas semelhantes ao embrião zigótico, porém sem que ocorra fusão de gametas (Guerra et al, 1999).

Inicialmente, a importância do cultivo de calos nucelares na obtenção de embriões somáticos estava relacionada com a obtenção de plantas livres de vírus. Posteriormente, o interesse pela embriogênese se intensificou pela possibilidade de obtenção de um grande número de embriões somáticos (Cristofani, 1991) e também sua utilização na hibridação somática e 
transformação genética (Komatsuda et al., 1992; Luo et al., 2003). Entretanto, a falta de conhecimento dos fatores que controlam a embriogênese somática, a assincronia do desenvolvimento desses embriões, e a baixa conversão dos mesmos em plantas são responsáveis pela sua reduzida aplicação comercial (Pedroso \& Pais, 1985).

A embriogênese somática já foi relatada em várias espécies de citros com diferentes resultados em termos de conversão em plantas, tendo sido observada principalmente a partir de calos originados de cultivo de óvulos e nucelos (Kochba et al., 1982; Button \& Bornman, 1971). Tem-se observado que tanto a qualidade, quanto a quantidade de embriões somáticos produzidos depende não somente de fatores genéticos e fisiológicos, mas também de condições ambientais em que a cultura de calos é mantida. A ausência de sincronia durante o desenvolvimento de embriões somáticos de citros já foi relatada por alguns autores (Moore, 1985; Perez et al.,1998; Tomaz et al., 2001).

Lee et al. (2001) relatam que períodos de estresse durante o cultivo in vitro, tais como dessecação, frio e calor podem promover aumentos nas taxas de indução, maturação e germinação de embriões somáticos, concluindo-se que as condições físicas e químicas da cultura desempenham um importante papel na indução e conversão de embriões em plantas.

De acordo com Lee et al. (2001), períodos de dessecação na cultura podem melhorar a taxa de germinação e o número de embriões somáticos em cenoura. Janeiro et al. (1995) relatam que o tratamento de culturas a baixas temperaturas também promove a maturação e a capacidade de germinação de embriões somáticos em diferentes espécies. Merkle et al. (1990) descrevem que a separação de agregados celulares favorece a sincronização do desenvolvimento dos embriões somáticos. Apesar disso, o efeito de variáveis fisiológicas controladas, não tem sido sistematicamente explorado com respeito à indução de embriões somáticos (Krul, 1993). 
Assim, o objetivo deste trabalho foi avaliar o efeito de alguns tratamentos tais como: dessecação, frio e tamanho de agrupamentos celulares, na indução, sincronização, e uniformidade da embriogênese somática de Citrus sinensis L. Osbeck, variedade Valência.

\subsection{Material e Métodos}

\subsubsection{Cultivo In Vitro}

Os experimentos foram realizados utilizando-se calos nucelares de laranja 'Valência' (C. sinensis L. Osbeck), cultivados em meio de multiplicação EME (Gosser \& Gmitter Junior, 1990a), solidificado com 8,0 $\mathrm{g} \mathrm{L}^{-1}$ de ágar, suplementado com $50 \mathrm{~g} \mathrm{~L}^{-1}$ de sacarose e $0,5 \mathrm{~g} \mathrm{~L}^{-1}$ de extrato de malte, subcultivados a cada 4 semanas, e mantidos em câmara tipo B.O.D., a $27 \pm 1^{\circ} \mathrm{C}$, no escuro.

\subsubsection{Obtenção de Embriogênese Somática}

Para a indução da embriogênese somática, calos cultivados em meio de multiplicação foram coletados e transferidos para o mesmo meio, porém líquido, mantidos em agitador orbital a $200 \mathrm{rpm}$, durante 24h, e finalmente peneirados, ou não, de acordo com o tratamento. As peneiras utilizadas apresentaram malhas de $150 \mu \mathrm{m}$ (P1), $300 \mu \mathrm{m}$ (P2) e $600 \mu \mathrm{m}$ (P3) (Figura 10).

Além do efeito do tamanho de agregados celulares, também foi observado o efeito de exposição ao frio ou dessecação. Neste sentido, os calos foram colocados em meio de indução da embriogênese EME suplementado com $13,4 \mathrm{~g} \mathrm{~L}^{-1}$ de maltose e $0,5 \mathrm{~g} \mathrm{~L}^{-1}$ de extrato de malte, e mantidos em geladeira a $4^{\circ} \mathrm{C}$, durante quatro semanas, sob ausência de luz. Após este período, as placas de Petri contendo os calos foram transferidas para câmara 
de crescimento do tipo B.O.D., à temperatura de $26 \pm 1^{\circ} \mathrm{C}$ e intensidade luminosa de 300 lux.

No tratamento de dessecação, os calos foram colocados em placas de Petri, em ausência de meio de cultura, e mantidos em câmara do tipo B.O.D., a $27 \pm 1^{\circ} \mathrm{C}$, por um período de 6 dias no escuro. Após este período os calos foram transferidos para meio de cultura de indução da embriogênese somática, conforme procedimento descrito por Tomaz et al. (2001).

Como testemunha foram utilizados calos peneirados e sem peneirar, os quais foram diretamente introduzidos em meio de cultura para a obtenção de embriões somáticos, seguindo-se o protocolo descrito por Tomaz et al. (2001).

\subsubsection{Avaliações}

O experimento foi delineado em 3 blocos casualizados, formando um esquema fatorial $4 \times 3$ e resultando em 12 tratamentos com 4 repetições:

T1 - Peneira 1 e sem tratamento de estresse;

T2 - Peneira 1 e frio;

T3 - Peneira 1 e dessecação;

T4 - Peneira 2 e sem tratamento de estresse;

T5 - Peneira 2 e frio;

T6 - Peneira 2 e dessecação;

T7 - Peneira 3 e sem tratamento de estresse;

T8 - Peneira 3 e frio;

T9 - Peneira 3 e dessecação;

T10 - Sem peneirar e sem tratamento de estresse;

T11 - Sem peneirar e frio;

T12 - Sem peneirar e dessecação. 

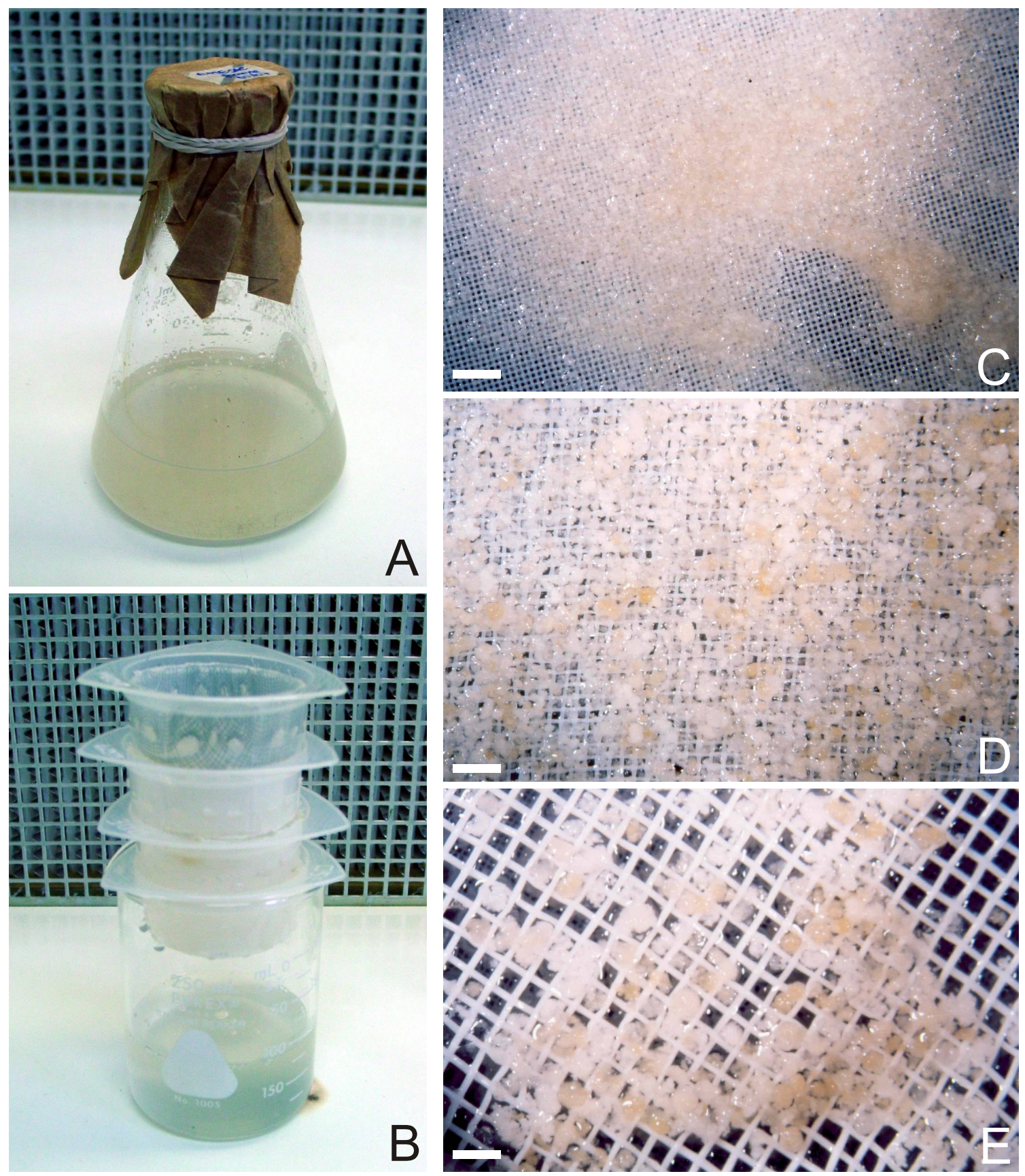

Figura 10 - Experimento de separação de agrupamentos celulares de laranja 'Valência' através de diferentes tamanhos de peneiras. A) Erlenmeyer contendo cultura em suspensão em meio de multiplicação, contendo sacarose; B) sistema de peneiras para separação dos agregados celulares; C-E) Características gerais dos calos após separação em peneira $1=150 \mu \mathrm{m}(\mathrm{C})$, peneira $2=300 \mu \mathrm{m}$ (D) e peneira $3=600 \mu \mathrm{m}(\mathrm{E})$ 
Foram realizadas avaliações visuais aos 30 e 60 dias, em microscópio estereoscópico, determinando-se porcentagem de culturas responsivas, a freqüência e o estágio de desenvolvimento dos embriões somáticos, e desta forma, avaliando-se o sincronismo do desenvolvimento como resposta aos diferentes tratamentos.

\subsubsection{Análises Anatômicas e Histoquímicas}

As análises anatômicas foram realizadas através de cortes histológicos avaliados através de microscopia óptica. Para tanto, foram coletadas amostras de calos em cada tratamento nos tempos: 0, 7, 15 e 30 dias. As amostras de calos foram preparadas para realização das análises anatômicas de acordo com Rodriguez \& Wetzstein (1998). Para isso, as amostras foram fixadas por um período mínimo de $8 \mathrm{~h}$ em solução de paraformaldeído $(4 \%, p / v)$. Após a fixação, os tecidos foram lentamente desidratados à temperatura ambiente em uma série de (100\%) metil cellosolve, etanol, propanol e butanol. A infiltração foi realizada inicialmente em uma solução de butanol e meio de infiltração (proporção de $3: 1 ; 1: 1 ; 1: 3$ ), trocandose a cada $2 \mathrm{~h}$, à temperatura de $4^{\circ} \mathrm{C}$, e posteriormente, em meio de infiltração (100\%), por $24 \mathrm{~h}$, ou até as amostras ficassem translúcidas e no fundo do recipiente.

Para infiltração e emblocagem das amostras foi utilizado o kit Historesin (hidroxietilmetacrilato, Leica Heidelberg). A polimerização foi realizada à temperatura ambiente por 2 a 4 dias. Em seguida, foram realizados cortes seriados com espessura de $5 \mu \mathrm{m}$ em micrótomo rotativo (Leica RM2155), corados por 1 a 2 minutos em fucsina ácida (0,1\%), seguido de 1 a 2 minutos em azul de toluidina (0,05\%), conforme Feder \& O'Brien (1968).

Para as análises histoquímicas os cortes histológicos foram corados para detecção de proteínas com comassie blue $(0,25 \%$ em $3 \%$ de ácido acético), por 3 minutos, depois foram lavados e imersos por $24 \mathrm{~h}$ em ácido 
acético glacial (3\%). Para observação de amido, cortes histológicos foram corados com lugol por 1 a 2 minutos. Posteriormente, os cortes histológicos foram observados e fotografados em microscópio óptico invertido (Zeiss Axiovert).

\subsection{Resultados e Discussão}

A separação de calos em agregados celulares de tamanhos diferentes e avaliação de suas características estruturais e histoquímicas mostraram que agregados de diferentes tamanhos podem apresentar diferentes características estruturais e de composição celular, em relação aos parâmetros estudados.

As análises histológicas evidenciaram nos calos a presença de três tipos distintos de agrupamentos celulares. O primeiro grupo, presente em maior número nos calos separados pela peneira P1 $(150 \mu \mathrm{m})$, apresentou células pequenas, arredondadas, homogêneas, com núcleo evidente e elevada freqüência de divisões celulares. O segundo grupo, formado por células maiores, contendo vacúolo volumoso, núcleo menos evidente e menor freqüência de divisões celulares, foi observado em maior quantidade nos calos separados pela peneira P2 $(300 \mu \mathrm{m})$. O terceiro grupo, observado mais freqüentemente nos calos obtidos após separação em P3 $(600 \mu \mathrm{m})$, apresentaram células em sua maioria grandes, heterogêneas, com vacúolos proeminentes, núcleo pouco evidente, menos túrgidas e apresentando baixa freqüência de divisões celulares (Figuras 11A, C, E).

As análises histoquímicas dos diferentes tamanhos e tipos de agregados celulares mostraram maior acúmulo de proteínas nas células do grupo 1 , sendo a distribuição de proteínas uniforme na célula, indicando citoplasma denso e elevada atividade metabólica. Nos grupos dois e três, a coloração referente a proteínas era concentrada no núcleo, demonstrando a 


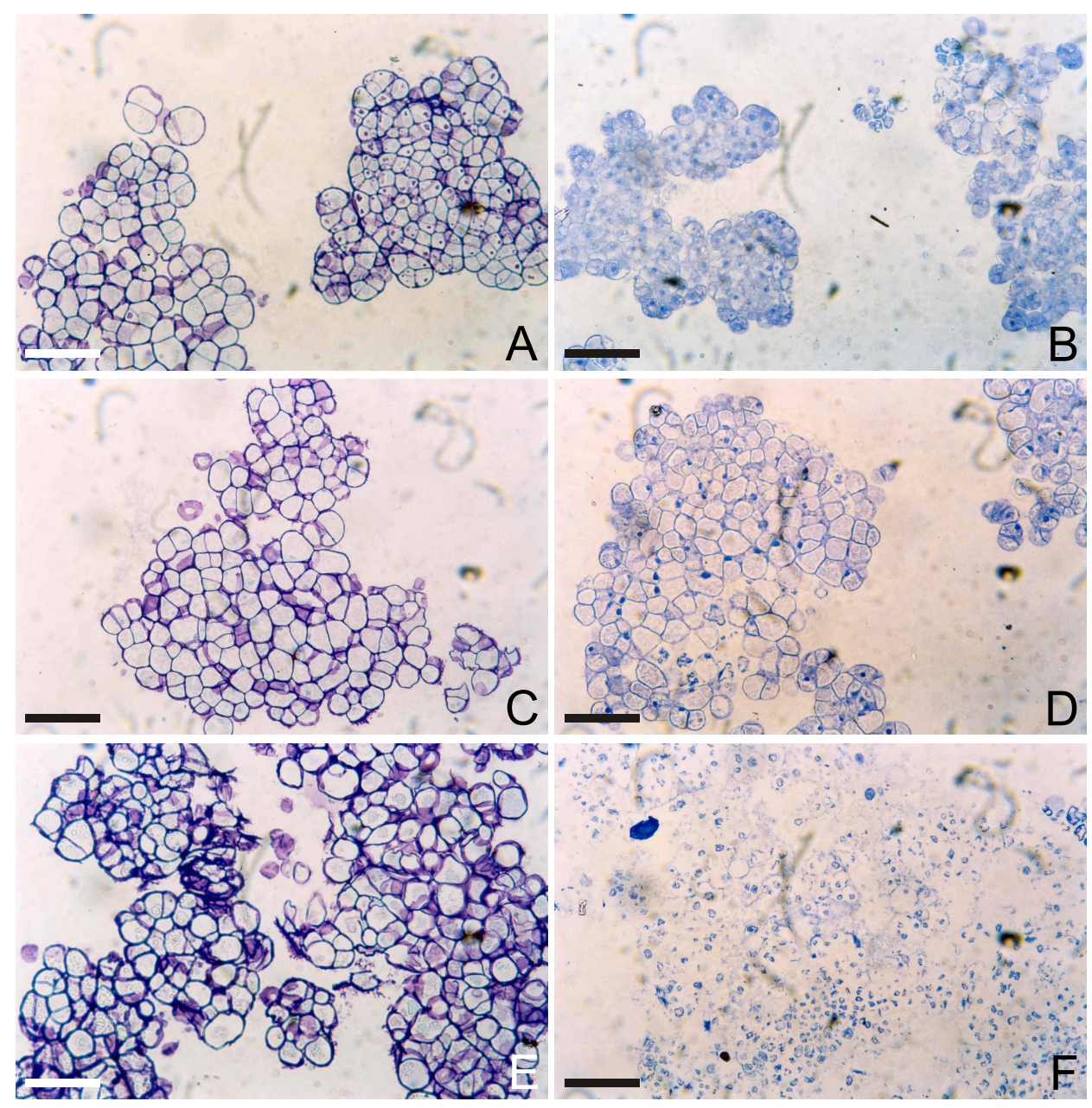

Figura 11 - Características estruturais $(A, C, E)$ e de acúmulo de proteínas $(B, D, F)$ de calos nucelares de laranja 'Valência', separados por tamanho, através de peneiras com diferentes malhas. Calos em peneira $1(150 \mu \mathrm{m})$ corados em azul de toluidina e fucsina ácida (A), e azul de comassie (B); calos em peneira 2 (300 $\mu \mathrm{m})$ corados em azul de toluidina e fucsina ácida (C), e azul de comassie (D); calos em peneira $3(600 \mu \mathrm{m})$ corados em azul de toluidina e fucsina ácida (E), e azul de comassie (F), mostrando que agregados de tamanhos distintos apresentam diferentes características estruturais e de acúmulo de reservas. Barras $=100 \mu \mathrm{m}$ ) 
presença de um vacúolo maior e citoplasma reduzido, com baixa atividade metabólica (Figuras 11B, D, F).

Goldberg et al. (1994) relatam que muitos genes são ativados durante a embriogênese, sendo responsáveis pelo desenvolvimento do processo. Os genes ativos podem ser observados através de seus produtos, ou seja, proteínas e enzimas, o que leva a um maior acúmulo das mesmas na célula durante este período.

Após sete dias em meio para obtenção de embriões, em todos os tratamentos (tamanho dos agrupamentos celulares e estresse), observou-se que os grupos 2 e 3, que apresentavam baixa atividade mitótica, apresentavam uma elevação na freqüência de divisões celulares, com células apresentando núcleo e citoplasma mais evidentes e um aumento no acúmulo de proteínas evidenciado pela coloração mais intensa do azul de comassie, evidenciando, portanto, um aumento na atividade metabólica. Nas células do grupo 1, que inicialmente já apresentavam divisões celulares freqüentes, observou-se um acréscimo ainda mais expressivo no acúmulo de proteínas.

De maneira geral, as células com maior freqüência de divisões mitóticas, quando coradas com lugol, apresentaram uma menor concentração de grãos de amido, quando comparadas às células em menor atividade mitótica. Este comportamento possivelmente está relacionado à elevada demanda de energia nas células em alta freqüência de divisões celulares e atividade metabólica, culminando em um consumo das reservas energéticas da célula.

De acordo com Lee et al. (2001), para algumas espécies, em particular, condições normais de cultivo in vitro podem não ser ótimas para a produção, crescimento e desenvolvimento de embriões somáticos. Tais condições podem resultar em perda de totipotência e estímulo à proliferação de calos, com baixas taxas de formação de embriões e conversão destes em plantas. 
Durante o tratamento de frio $\left(4^{\circ} \mathrm{C}\right.$ por 30 dias), houve inibição da embriogênese somática, sendo que ao serem transferidos para em temperatura de $26^{\circ} \mathrm{C}$, após alguns dias, deu-se início à formação de embriões somáticos. Aos 60 dias, notou-se que as culturas apresentaram sincronicamente grande quantidade de embriões em estádio globular, e que posteriormente estes evoluíram para as fases padrão de desenvolvimento.

Em Camélia sp., o armazenamento a frio de embriões somáticos reduziu a competência das culturas para embriogênese secundária, aumentando porém a capacidade de germinação e desenvolvimento de plântulas (Janeiro et al.,1995). Luo et al. (2003) relataram que a capacidade de células em suspensão, de Astragallus adsurgens Pall., produzirem embriões somáticos foi influenciada consideravelmente pela duração do tratamento de frio. Culturas pré-tratadas por um período de 2 a 3 semanas, a $8^{\circ} \mathrm{C}$, apresentaram resultados significativamente melhores. Segundo (Krul, 1993), o pré-tratamento com frio pode estimular a formação de massas préembriogênicas nas culturas celulares, o que resulta em um aumento da embriogênese somática. Contudo, de acordo com Luo et al. (2003), o papel do tratamento com frio, no aumento da embriogênese somática, é em grande parte desconhecido.

Em relação à freqüência embriogênica, ou seja, a freqüência de formação de embriões em cada placa embriogênica, a separação em diferentes tamanhos de agregados celulares resultou em resultados diferenciados (Figura 12). As peneiras que tiveram resultados mais expressivos foram $P 1$ e $P 2$, respectivamente, $150 \mu \mathrm{m}$ e $300 \mu \mathrm{m}$. Anandarajah \& Mckersie (1990) utilizaram células em suspensão peneiradas $(200 \mu \mathrm{m}-500 \mu \mathrm{m})$ para sincronizar o desenvolvimento de embriões somáticos em alfafa (Medicago sativa $\mathrm{L}$ ), tendo obtido resultados positivos, comparando-se às culturas sem peneiragem, contendo agregados de tamanhos variáveis. 
Figura 12 - Características das culturas de laranja 'Valência', após 60 dias em cultivo, em diferentes tratamentos de sincronização da embriogênese somática. Tratamento 1 (A-B); Tratamento 4 (C-D), Tratamento 7 (E-F), Tratamento $10(\mathrm{G}-\mathrm{H})$, evidenciando maior presença de embriões por placa, nos tratamentos com peneiras de $150 \mu \mathrm{m}$ e $300 \mu \mathrm{m}$, respectivamente tratamentos 1 e 2 . Barras $=1000$ $\mu \mathrm{m}$ 

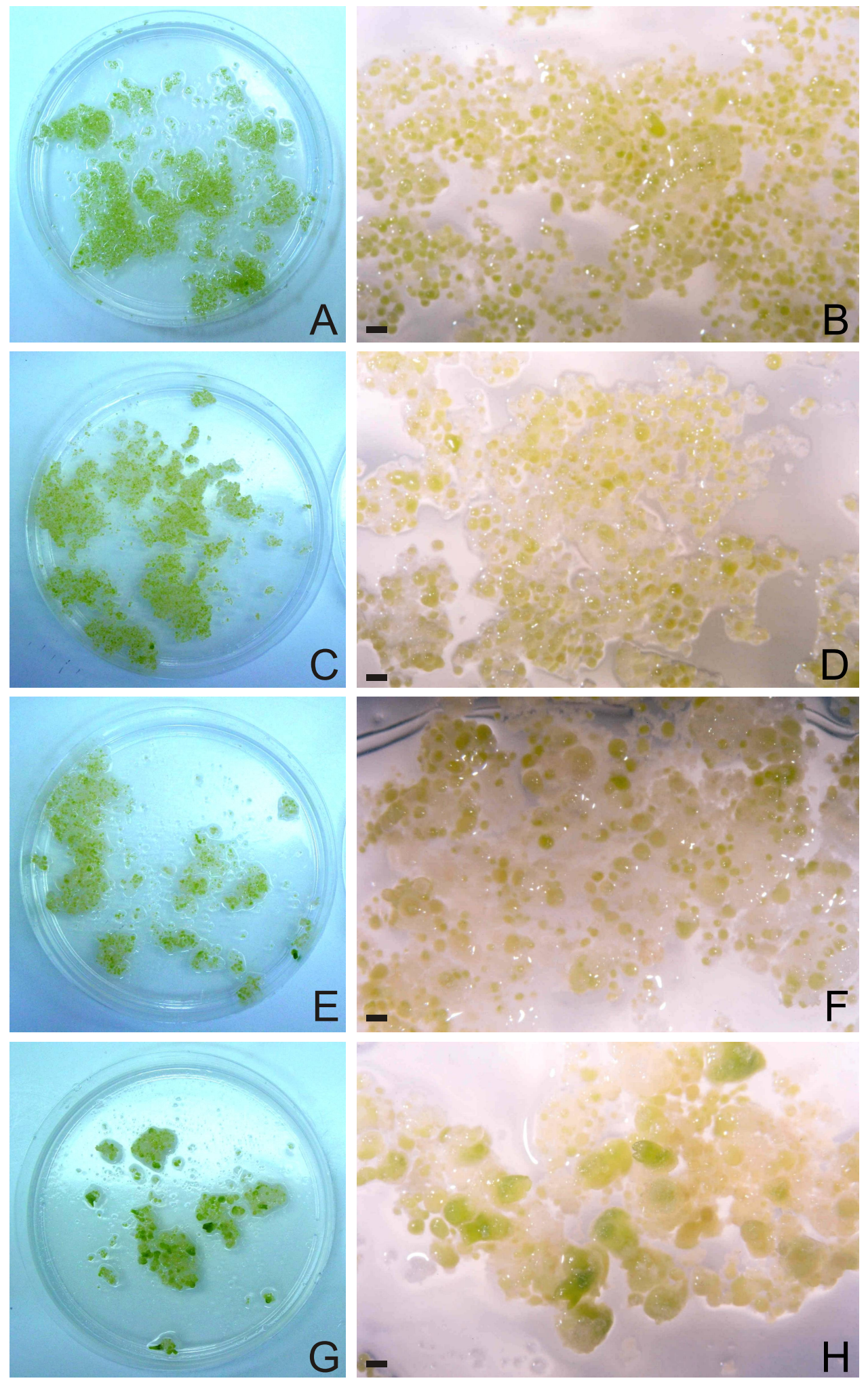
Ikeda-Iwai et al. (2003) estudaram vários tratamentos de estresse (metal pesado, estresse osmótico e desidratação) para a indução da embriogênese somática de Arabidopsis thaliana. Os autores relataram que as condições foram favoráveis à indução da embriogênese, e que a freqüência de formação dos embriões foi dependente do tipo e da duração do tratamento de estresse.

As condições de cultivo apresentam um importante papel na indução, desenvolvimento e conversão de embriões somáticos. De acordo com Lee et al. (2001), a dessecação de cultura de células inibe a proliferação normal de células indiferenciadas, estimulando desta forma, a produção de embriões somáticos e a sincronização do desenvolvimento destes embriões. Wetzstein et al. (1990) observaram que tratamento de dessecação seguido de tratamento de frio em culturas de pecan (Carya illinoensis) melhorou o desenvolvimento de embriões somáticos.

Os resultados obtidos (Tabela 1) sugerem que as peneiras P1 $(150 \mu \mathrm{m})$ e P2 $(300 \mu \mathrm{m})$ permitiram uma maior freqüência e indução de embriões por placa em relação à testemunha. Confirma-se assim, a hipótese de que a formação de embriões somáticos ocorre a partir de agregados celulares de tamanhos específicos, já que com a utilização das peneiras 1 e 2, onde o material apresentava tamanho de agregados inferior a $300 \mu \mathrm{m}$, a freqüência de embriões é mais elevada do que na testemunha. Utilizando-se a peneira com maior malha $(600 \mu \mathrm{m})$, ou seja, com material apresentando agrupamentos celulares maiores, a freqüência de embriões foi menor do que na testemunha, onde havia agrupamentos celulares de todos os tamanhos. Pode-se dizer que o fator peneira foi superior ao fator estresse em relação à produção e desenvolvimento dos embriões somáticos.

Merkle et al. (1990) realizaram experimentos visando sincronizar o desenvolvimento de embriões somáticos a partir de massas pré-embriogênicas (PEMs) de Liriodendron tulipifera, separando estas com peneiras de tamanhos 
diferentes. O fracionamento teve dois efeitos benéficos na embriogênese somática: sincronizou o desenvolvimento dos embriões somáticos, e acelerou a diferenciação dos embriões somáticos.

Tabela 1. Avaliação da influência do estresse e separação de agrupamentos celulares na embriogênese somática de laranja 'Valência', a partir de calos nucelares, aos 60 dias*$^{\star}$.

\begin{tabular}{|c|c|c|}
\hline Tratamentos & Indução de Culturas (\%) $)^{\star \star}$ & Freqüência (\%)*** \\
\hline T1 & 75 & 75 \\
\hline T2 & 75 & 82 \\
\hline T3 & 100 & 94 \\
\hline T4 & 100 & 100 \\
\hline T5 & 88 & 82 \\
\hline T6 & 100 & 79 \\
\hline $\mathrm{T} 7$ & 75 & 45 \\
\hline T8 & 63 & 30 \\
\hline T9 & 88 & 26 \\
\hline T10 & 50 & 28 \\
\hline T11 & 88 & 55 \\
\hline T12 & 75 & 53 \\
\hline
\end{tabular}

Os tratamentos com a combinação de peneiras de 150 e $300 \mu \mathrm{m}$ e as condições de frio e dessecação tiveram predominância de embriões globulares, evidenciando que estes tratamentos foram efetivos na sincronização do desenvolvimento dos embriões somáticos.

De maneira geral, a formação de embriões somáticos anormais foi observada em todos os tratamentos. Inversamente, em culturas de Liriodendron 
tulipifera as massas celulares pré-embriônicas (PEMs) fracionadas por peneiras pareceram seguir um padrão de desenvolvimento normal, pelo menos no estágio globular (Merkle et al.,1990).

De acordo com Ikeda-Iwai et al. (2003), cada tratamento de estresse induz a uma reação comum que está relacionada à desdiferenciação e rediferenciação da célula somática vegetal o que leva à embriogênese somática. Isto sugere que cada estresse pode induzir a expressão de um fator que controla o início da embriogênese somática através de uma reação comum.

\subsection{Conclusões}

Os resultados obtidos neste experimento sugerem que a separação de agrupamentos celulares e as condições de estresse testadas, influenciam a indução e a sincronização de embriões somáticos de $C$. sinensis, var. Valência. Melhor sincronização das culturas e maior eficiência de obtenção de embriões somáticos foi observada em todos os tratamentos, em relação à testemunha, sendo que a combinação de separação de agregados celulares com tratamento de estresse apresentou os melhores resultados. Entre os tratamentos, a separação dos agregados celulares mostrou que as culturas produzem embriões somáticos mais eficientemente a partir de agregados celulares de tamanho específico (menor do que $300 \mu \mathrm{m}$ ). 


\section{CONCLUSÕES GERAIS}

De acordo com os resultados e nas condições em que foi desenvolvido o trabalho, pôde-se concluir que para as duas condições observadas, meio de multiplicação, com sacarose, e meio de obtenção de embriões, com maltose, existem diferenças anatômicas e histoquímicas entre as duas espécies de citros, sendo que as culturas de laranja "Valência' apresentam maior quantidade de agregados celulares com características embriogênicas, confirmando a maior eficiência em produção de embriões somáticos em laranja 'Valência'.

O sinal de expressão do gene AtSERK1 foi observado nos calos de ambas as espécies de citros, mesmo antes de transferência para meio de obtenção de embriões, evidenciando que a cultura possui células competentes para a embriogênese somática. A observação da expressão gênica confirma a conservação dos genes entre $A$. thaliana e as espécies de citros estudadas, além da conservação da expressão desse gene entre a embriogênese zigótica e somática.

Os tratamentos de separação de agrupamentos celulares de calos e condições de estresse são eficientes para a indução e a sincronização de embriões somáticos em culturas de calos de $C$. sinensis, var. Valência, sendo que embriões somáticos são mais eficientemente obtidos a partir de agregados celulares menores do que $300 \mu \mathrm{m}$. 


\section{REFERÊNCIAS BIBLIOGRÁFICAS}

ALMEIDA, W.A.B. de; MOURÃO FILHO, F.A.A.; MENDES, B.M.J.; RODRIGUEZ, A.P.M. In vitro organogenesis optimization and plantlet regeneration in Citrus sinensis and C. limonia. Scientia Agricola, v.59, n.1, p.35-40, 2002.

AMMIRATO, P.V. Organizational events during somatic embryogenesis. In: GREEN, C.E.; SOMERS, D.A.; HACKETT, W.P.; BIESBOER, D.D.(Ed.). Plant tissue and cell culture. New York: Alan R. Liss, 1987. p.57-81.

ANANDARAJAH, K.; McKERSIE, B. D.; Manipulating the desiccation tolerance and vigor of dry somatic embryos of Medicago sativa $L$ with sucrose, heat shock and absicic acid. Plant Cell Reports, v.9, p.451-455, 1990.

BAUDINO, S.; HANSEN, S.; BRETTSCHNEIDER, R.; HECHT, V.F.G.; DRESSELHAUS, T.; LÖRZ, H.; DUMAS, C.; ROGOWSKY, P.M. Molecular characterisation of two novel maize LRR receptor-like kinases, which belong to the SERK gene family. Planta, v.213, p.1-10, 2001.

BENEDITO, V.A.; MOURÃO FILHO, F.A.A.; MENDES, B.M.J. Calogênese, embriogênese somática e isolamento de protoplastos em variedades de laranja doce. Scientia Agricola, v.57, n. 1, p. 33-38, 2000. 
BEWLEY, J. D.; BLACK, M. Seeds: Physiology of Development and germination. 2.ed. New York : Plenum Press, 1994. 445p.

BOWMAN, J.L. The YABBY gene family and abaxial cell fate. Current Opinion in Plant Biology, v.3, p.17-22, 2000.

BUCHANAN, B.B. GRUISSEM, W.; JONES, R.L. Biochemistry \& molecular biology of plant. Berkeley: Courier, 2000. 1367p.

BUTTON, J.; BORNMAN, C.H. Development of nucellar plants from unpollinated and unfertilized ovules of Washington navel orange in vivo. Journal of South African of Botany, v.37, n.2, p.127-134, 1971.

BUTTON, J.; KOCHBA, J.; BORNMAN, C.H. Fine structure of and embryoid development from embryogenic ovular callus of 'Shamouti' orange (Citrus sinensis Osb.). Journal of Experimental Botany, v.25, n.85, p.446-457, 1974.

CABASSON, C.; OLLITRAULT, P.; CÔTE, F-X.; MICHAUX-FERRIÈRE, N.; DAMBIER, D.; DALNIC, R.; TEISSON, C. Characteristics of Citrus cell cultures during undifferentiated growth on sucrose and somatic embryogenesis on galactose. Physiologia Plantarum, v.93, p.464-470, 1995.

CRISTOFANI, M. Uso da cultura de tecidos no melhoramento de citros. Laranja, v.12, n.2, p.449-453, 1991.

CROUCH, M.L. Non-zigotic embryos of Brassica napus contain embryo-specific storage proteins. Planta, v.156, p.520-524, 1982. 
DAVIES, F.S.; ALBRIGO, L.G. Citrus. Wallingford: CAB International, 1994. $252 p$.

DE VRIES, S.C.; BOOIJ, H.; MEYERINK, P.; HUISMAN, G.; WILDE, H.D.; THOMAS, T.L.; VAN KAMMEN, A. Acquisition of embryogenic potential in carrot cell-suspension cultures. Planta, v.176, p.196-204, 1988.

DE VRIES, S.C. Making embryos in plants. Trends in Plant Science, v.3, n.12, p.451-452, 1998.

DORNELAS, M.C.; VIEIRA, M.L.C.; APPEZZATO-DA-GLÓRIA, B. Histological analysis of organogenesis and somatic embryogenesis induced in immature tissues of Stylosanthes scabra. Annals of Botany, v.70, p.477-482, 1992.

DORNELAS, M.C.; WITTICH, P.; VON RECKLINGHAUSEN, I.; VAN LAMMEREN, A.A.M.; KREIS, M. Characterization of three novel members of Arabidopsis SHAGGY-related protein kinase (ASK) multigene family. Plant Molecular Biology, v.39, p.137-147, 1999.

DRONNE, S.; LABEL, P.; LELU, M.-A. Desiccation decreases abscisic acid content in hybrid larch (Larix $\mathrm{x}$ leptoeuropaea) somatic embryos. Physiologia Plantarum, v.99, p.433-438, 1997.

FAO. FAOSTAT - Statistics Database. http://apps.fao.org/ (14 fev. 2003).

FEDER, N.; O'BRIEN, T. P.Plant microtechnique: Some principles and new methods. American Journal of Botany, v.55, p.123-142, 1968. 
FLOH, E.I.S.; HANDRO, W. Variation of histological patterns in tobacco callus during successive subcultures. Canadian Journal of Botany, v.63, p.17941800, 1985.

FNP CONSULTORIA \& COMÉRCIO. AGRIANUAL 2003: Anuário da agricultura brasileira. São Paulo, 2003. p.295-344.

FOSKET, D.E. Plant growth and development: A molecular approach. Irwine: Academic Press, 1994. 580p.

FUNDECITRUS. http://www.fundecitrus.com.br/ (14 fev. 2003).

GAVISH, H.; VARDI, A.; FLUHR, R. Extracelullar proteins and early embryo development in Citrus nucellar cell cultures. Physiologia Plantarum, v.82, p.606-616, 1991.

GMITTER JUNIOR, F.G.; LING, X.B.; DENG, X.X. Induction of triploid Citrus plants from endosperm calli in vitro. Theoretical And Applied Genetics, v. 80, p.785-790, 1990.

GMITTER JUNIOR, F.G.; MOORE, G.A. Plant regeneration from developed ovules and embryogenic calli of citrus: Embryo production, germination, and plant survival. Plant Cell, Tissue and Organ Culture, v.6, p.139-147, 1986.

GOLDBERG, R.B.; BARKER, S.J.; PEREZ-GRAU, L. Regulation of gene expression during plant embryogenesis. Cell, v.56, p.149-160, 1989.

GOLDBERG, R.B.; de PAIVA, G.; YADEGARI, R. Plant embryogenesis: zygote to seed. Science, v.266, p.605-614, 1994. 
GOSAL, S.S.; GILL, M.I.S.; GREWAL, H.S. Somatic embryogenesis in Citrus species. In: JAIN, S.M.; GUPTA, P.K.; NEWTON, R.J. (Ed.) Somatic embryogenesis in woody plants. Dordrecht: Kluwer Academic, 1995. v.2, p.1-21.

GRATTAPAGLIA, D.; MACHADO, M.A. Micropropagação. In: TORRES, A.C.; CALDAS, L.S.; BUSO, J.A. Cultura de tecidos e transformação genética de plantas. Brasília: EMBRAPA, SPI; EMBRAPA, CNPH, 1998. v.1, p.186260.

GROSSER, J.W.; GMITTER JUNIOR, F.G. Protoplast fusion and citrus improvement. Plant Breeding Reviews, v.8, p.339-374, 1990.

GUERRA, P.M.; TORRES, A.C.; TEIXEIRA, J.B. Embriogênese somática e sementes sintéticas. In: TORRES, A.C.; CALDAS, L.S.; BUSO, J.A. Cultura de tecidos e transformação genética de plantas. Brasília: Embrapa Produção de Informação; Embrapa Hortaliças, 1999. v.2, p.533568.

HACCIUS, B. Question of unicellular origin of non-zygotic embryos in callus culture. Phytomorphology, v.28, p.74-81, 1978.

HECHT, V.; VIELLE-CALZADA, J.P.; HARTOG, M.V.; SCHMIDT, D.L.; BOUTILIER, K.; GROSSNIKLAUS, U.; DE VRIES, S.C. The Arabidopsis SOMATIC EMBRYOGENESIS RECEPTOR KINASE 1 gene is expressed in developing ovules and embryos and enhances embryogenic competence culture. Plant Physiology, v.127, p.803-816, 2001. 
HIRAMATSU, J.K.; KOBAYASHI, S.; NAKAMURA, Y.; SHIGEMOTO, N.; DOI, $Y$. A simple and efficient gene transfers system of trifoliate orange (Poncirus trifoliata Raf.) Plant Cell Reports, v.13, n.10, p.541-545, 1994.

IKEDA-IWAI, M.; UMEHARA, M.; SATOH, S.; KAMADA, H. Stress-induced somatic embryogenesis in vegetative tissues of Arabidopsis thaliana. The Plant Journal, v.34, p. 107-114, 2003.

JANEIRO, L.V.; BALLESTER, A.; VIEITEZ, A.M. Effect of cold storage on somatic embryogenesis systems of Camellia. Journal of Horticultural Science, v.70, n.4, p.665-672, 1995.

JURGENS, G. Axis formation in plant embryogenesis: cues and clues. Cell, v.81, p.467-470, 1995.

KOBAYASHI, J.; SPIEGEL-ROY, H.N.; SAAD, S. Stimulation of embryogenesis in Citrus ovular callus by $\mathrm{ABA}$, ethephon, $\mathrm{CCC}$ and alar and its suppression by $\mathrm{GA}_{3}$. Zeitschrift fû́r Pflanzenphysiolgie, v.89, p.427-432, 1978.

KOBAYASHI, S.; OHGAWARA, T. Production of somatic hybrid plants through protoplast fusion in Citrus. Journal of Agriculture Reviews, v.22, n.3, p.181-188, 1988.

KOCHBA, J.; SPIEGEL-ROY, P. The effects of auxins, cytokinins and inhibitors on embryogenesis in habituated ovular callus of the 'Shamouti' orange ( $C$. sinensis). Zeitschrift fû́r Pflanzenphysiolgie, v.81, p.283-288, 1977.

KOCHBA, J.; SPIEGEL-ROY, P.; SAFRAN, H. Adventive plants from ovules and nucelli in Citrus. Planta, v.106, p.237-245, 1972. 
KOCHBA, J.; SPIEGEL-ROY, P.; NEUMANN, H.; SAAD, S. Stimulation of embryogenesis in Citrus ovular callus by ABA, Ethephon, CCC and Alar and suppression by $\mathrm{GA}_{3}$ Zeitschrift fur Pflanzenphysiolgie, v.89, p.427-432, 1978.

KOCHBA, J.; SPIEGEL-ROY, P.; NEUMANN, H.; SAAD, S. Effect of carbohydrates on somatic embryogenesis of subcultured nucellar callus of citrus cultivars. Zeitschrift fû́r Pflanzenphysiolgie, v.105, p.359-368, 1982.

KOMATSUDA, T.; LEE, W.; OKA, S. Maturation and germination of somatic embryos as affected by sucrose and plant growth regulators in soybeans Glycine gracilis Skvortz and Glicine $\max$ (L.) Merr. Plant Cell, Tissue and Organ Culture, v.28, p.103-113, 1992.

KRUL, W.R. Enhancement and repression of somatic embryogenesis in cell cultures of carrot by cold pretreatment of stock plants. Plant Cell, Tissue and Organ Culture, v. 32, n.3, p.271-276, 1993.

KUMARAN, M.K.; BOWMAN, J.L.; SUNDARESAN, V. YABBY polarity genes madiate the repression of KNOX homeobox genes in Arabidopsis. The Plant Cell, v. 14, p.2761-2770, 2002.

LECOUTEUX, C. G.; LAI, F.-M.; McKERSIE, B. D. Maturation of alfalfa (Medicago sativa L.) somatic embryos by abscisic acid, sucrose and chilling stress. Plant Science, v.94, p.207-213, 1993.

LEE, E.K.; CHO, D.Y.; SOH, W.Y. Enhanced production and germination of somatic embryos by temporary starvation in tissue culture of Daucus carota. Plant Cell Reports, v.20, p.408-415, 2001. 
LING, J.T.; IWAMASA, M. Somatic hybrydization between Citrus reticulata e Citropsis gabunensis through electrofusion. Plant Cell Reports, v.13, n.9, p.493-497, 1994.

LONG, J.A.; BARTON, M.K. The development of apical embryonic pattern in Arabidopsis. Development, v.125, p.3027-3035, 1998.

LU, P.; PORAT, R.; NADEAU, J.A.; O'NEILL, S.D. Identification of a meristem L1 layer-specific gene in Arabidopsis that is expressed during embryogenic pattern formation and defines a new class of homeobox genes. Plant Cell, v.8, p.2155-2168, 1996.

LUO, J-P.; JIANG, S-T.; PAN, L-J. Cold-enhanced somatic embryogenesis in cell suspension cultures of Astragalus adsurgens Pall.: relationship with exogenous calcium during cold pretreatment. Plant Growth Regulation, v.40, p.171-177, 2003.

MACHADO, M.A. Biotecn ologia na citricultura. Biotecnologia e Desenvolvimento, v.1, n.1, p.8-10, 1997.

MENDES, B.M.J.; BOSCARIOL, R.L.; MOURÃO FILHO, F.A.A.; ALMEIDA, W.A.B. de. Agrobacterium-mediated genetic transformation of 'Hamlin' sweet orange. Pesquisa Agropecuária Brasileira, v.37, n.7, p.955-961, 2002.

MENDES-DA-GLÓRIA, F.J.; MOURÃO FILHO, F.A.A.; MENDES, B.M.J. Regeneração de plantas após fusão e cultura de protoplasto de laranja 'Caipira' (Citrus sinensis L. Osbeck) e limão 'Cravo' (Citrus limonia L. Osbeck). In: ENCONTRO BRASILEIRO DE BIOTECNOLOGIA VEGETAL, 2., Gramado, 1997. Resumos. Gramado, 1997. 
MENDES-DA-GLÓRIA, F.J.; MOURÃO FILHO, F.A.A.; APEZZATO-DAGLÓRIA, B. Morfologia de embriões nucelares de laranja 'Valência' (Citrus sinensis L. Osbeck). Acta Botanica Brasilica. v.15, n.1, p.17-25, 2001.

MERKLE, S.A.; WIECKO, A.T.; SOTAK, R.J.; SOMMER, H.E. Maturation and conversion of Liriodendron tulipifera somatic embryos. In Vitro Cellular Developmental Biology, v.26, p.1086-1093, 1990.

MISRA, S.; ATTREE, S. M.; LEAL, I.; FOWKW, L. C. Effect of abscisic acid, osmoticum, and desiccation on synthesis of storage proteins during the development of white spruce somatic embryos. Annals of Botany, v.71, p.11-22, 1993.

MOORE, G.A. Factors affecting in vitro embryogenesis from undeveloped ovules of mature Citrus fruit. Journal of the America Society for Horticultural Science, v.110, n.1, p.66-70, 1985.

MORDHORST, A.P.; LORZ, H. Embryogenesis and development of isolated barley (Hordeum vulgare L.) microspores are influenced by the amount and composition of nitrogen sources in culture media. Journal Plant Physiology. v.142, p.485-492, 1993.

MOURÃO FILHO, F.A.A.; GROSSER, J.W. Callus induction from Citrus relatives: an alternative source of protoplasts for somatic hybridization experiments. Proceedings of the Florida State Horticultural Society, v.105, p.52-56, 1992. 
MURASHIGE, T.; TUCKER, D.P.H. Growth factor requirements of citrus tissue culture. In: CITRUS SYMPOSIUM, 1., Riverside, 1969. Proceedings. Riverside: University of California, 1969. p.1155-1161.

OLIVEIRA, R.P. de; MENDES, B.M.J.; TULMANN NETO, A. Cultura de células em suspensão de 2 porta-enxertos de citros. Revista Brasileira de Fisiologia Vegetal, v.6, n.2, p.141-144, 1994b.

OLIVEIRA, R.P. de; MENDES, B.M.J.; TULMANN NETO, A. Obtenção e cultura de calos nucelares de limão 'Cravo', tangerina 'Cleópatra' e Poncirus trifoliata. Revista Brasileira de Fisiologia Vegetal, v.6, n.2, p.115-119, 1994a.

OLIVEIRA, R.P. de; ZANOL, G.C.; GONÇALVES, J.A.; SOARES FILHO, W.S. Calogênese em óvulos de espécies e variedades de Citrus. Revista Brasileira de Fruticultura, v.223, n.2, p.220-224, 2001.

OLLITRAULT, P.; LURO, F. Citrus breeding and biotechnology. Fruits, v.50, n.4, p.267-279, 1995.

PEDROSO, M.C.; PAIS, M.S. Factors controlling somatic embryogenesis. Plant Cell, Tissue and organ Culture, v.43, p.147-154, 1995.

PEÑA, L.; CERVERA, M.; JUÁREZ, J.; NAVARRO, A.; PINA, J. A.; DURÁNVILA, N.; NAVARRO, L. Agrobacterium-mediated transformation of sweet orange and regeneration of transgenic plants. Plant Cell Reports, v.14, p.616-619, 1995. 
PERES, L.E. As bases fisiológicas e genéticas da regeneração de plantas in vitro. Revista Biotecnologia Ciência \& Desenvolvimento, v.4, n.25, p.4448, 2002.

PEREZ, R.M.; GALIANA, A.M.; NAVARRO, L.; DURAN-VILA, N. Embryogenesis in vitro of Several Citrus species and cultivars. Journal of Horticultural Science \& Biotechnology, v.73, n.6, p.796-802, 1998.

RICCI, A. P.; MOURÃO FILHO, F. A. A.; MENDES, B. M. J.; PIEDADE, S. M. S. Somatic Embryogenesis in Citrus sinensis, C. reticulata and C. nobilis $\times$ C. deliciosa. Scientia Agricola, v. 59, n.1, p. 41-46, 2002.

RODRIGUEZ, A.P.M.; WETZSTEIN, H.Y The effect of auxin type and concentration on pecan (Carya illinoinensis) somatic embryo morphology and subsequent conversion into plants. Plant Cell Reports, v.13, p. 607611, 1994.

RODRIGUEZ, A.P.M.; WETZSTEIN, H.Y. A morphological and histological comparison of the initiation and development of pecan (Carya illinoinensis) somatic embryogenic cultures induced with naphthaleneacetic acid or 2,4dichlorophenoxyacetic acid. Protoplasma, v.204, p.71-83, 1998.

SCHMIDT, E.D.L.; GUZZO, F.; TOONEN, M.A.J.; DE VRIES, S.C. A leucin-rich repeat containing receptor-kinase marks somatic plant cells competent to form embryos. Development, v.124, p.2049-2062, 1997.

SESSIONS, A.; WEIGEL, D.; YANOFSKY, M.F. The arabidopsis thaliana MERISTEM LAYER 1 promoter specifies epidermal expression in meristems and young primordia. The Plant Journal, v.20, n.2, p.259-263, 1999. 
SHARP W.R. The physiology of in vitro asexual embryogenesis. Horticultural Reviews, v.2, p.268-310, 1980.

SIEGFRIED, K.R.; ESHED, Y.; BAUM, S.F.; OTSUGA, D.; DREWS, G.N.; BOWMAN, J.L. Members of the YABBY gene family specify abaxial cell fate in Arabidopsis. Development, v.126, p.4117-4128, 1999.

SIMÃO, S. Tratado de fruticultura. Piracicaba: FEALQ, 1998 . p.419-472: Citros.

SMITH, S.M.; STREET, H.E. The decline of embryogenic potential as callus and suspension cultures of carrot (Daucus carota L.) are serially subcultured. Annals of Botany, v.38, p.223-241, 1974.

SPIEGEL-ROY, P.; GOLDSCHMIDT, E.E. Biology of citrus. Cambridge: University Press, 1996. 230p. (Biology of Horticultural Crops).

SPIEGEL-ROY, P.; KOCHBA, J. Embryogenesis in Citrus tissue culture. In: FIECHTER, A. (Ed.). Advances in Biochemical Engineering. Berlin: Springer-Verlang, 1980. p.27-48.

STIRN, S.; MORDHORST, A.P.; FUCHS, S.; LÖRZ, H. Molecular and biochemical markers for embryogenic potential and regenerative capacity of barley (Hordeum vulgare L.) cell cultures. Plant Science, v.106, p.195-206, 1995.

THORPE, T.A. In vitro embryogenesis in plants. Dordrecht: Kluwer Academic, 1995. 558p. 
TOMAZ, M.L.; MENDES, B.J.M.; MOURÃO FILHO, F.A.A.; DEMÉTRIO, C.G.B.; JANSAKUL, N.; RODRIGUEZ, A.P.M. Somatic Embryogenesis in Citrus spp.: carbohydrate stimulation and histodiferentiation. In vitro Cell Developmental Biology Plant, v.37, p.446-452, 2001.

TOONEM, M.A.J. Embryo forming cells in carrot suspension cultures. Wageningen, 1997. 174p. Thesis (Doctor)- Wageningen Agricultural University.

TORRES, A.C.; CALDAS, L.S.; BUSO, J.A. Cultura de tecidos e transformação genética de plantas. Brasília: Embrapa Produção de Informação; Embrapa Hortaliças, 1999. v.1, p. 509.

VROEMEN, C. Molecular markers in Arabidopsis embryos. Wageningen, 1998. 155p. Thesis (Doctor) - Wageningen Agricultural University.

WETZSTEIN, H. Y.; MERKLE, S. A.; AULT, J. R. Factors influencing somatic embryogenesis and plantlet regeneration in pecan (Carya illinoensis). Acta Horticulturae, v. 280, p.69-73, 1990.

WILLIAMS, E.G.; MAHESWARAN, G. Somatic embryogenesis: factors influencing coordinated behaviour of cells as an embriogenic group. Annals of Botany, v.57, p.443-462, 1986.

WOLPERT, L.; BEDDINGTON, R.; BROCKES, J.; JESSELL, T.; LAWRENCE, P.; MEYEROWITZ, E. Princípios de biologia do desenvolvimento. Porto Alegre: ARTMED, 2000. 484p. 
YEUNG, E.C. The use of histology in the study of plant tissue culture systems: some practical comments. In Vitro Cell Developmental Biology Plant, v.35, p.137-143, 1999.

ZIMMERMAN, J.L. Somatic embryogenesis: a model for early development in higher plants. Plant Cell, v.5, p.1411-1423, 1993. 